\title{
Interfaces. Averiguaciones sobre los mundos intermediarios*
}

\author{
Gérard Chazal \\ Traducción del francés al español de Luis Alfonso Paláu-Castaño \\ Universidad Nacional de Colombia, sede Medellín, Colombia \\ lapalau@gmail.com
}

a Monsieur François Dagognet

\section{Introducción}

Una de las cuestiones fundamentales a las que toda interrogación filosófica termina por conducir es probablemente la del sentido. Inmediatamente, el sentido no es el objeto de una averiguación; está dado primitivamente como una evidencia inmediata. Una vez planteada la pregunta, en un segundo tiempo el filósofo se dedica a cuestionar esa evidencia como si ella velase un irritante misterio. Es solamente entonces cuando la averiguación comienza. Esta búsqueda pasa por un examen minucioso de todos los órdenes, de todas las estructuras, tanto las del universo como las que resultan de nuestras actividades más diversas. Hemos esbozado un examen tal en dos obras precedentes (Chazal, 2011, 2000). La idea vino porque no se podía reducir el sentido de una misteriosa presencia en una palabra, en un lenguaje. El sentido no se reduce al lenguaje, sino que lo desborda por todas partes. Perdura en el silencio. Podemos sospechar aún su presencia en el orden mineral cuando los gritos del viviente se extinguen. Así, poco a poco, en el curso de nuestras reflexiones, la noción de significación se encontró ligada a una noción mucho más general: la de forma. El sentido habita las cosas tanto como nos habita. A través de la forma física que esas cosas poseen las captamos les damos orden gracias a nuestra actividad informadora. El sentido se opone al caos como el orden al desorden, y es solo de esta manera que el lenguaje lleva significaciones sin que este sea la única fuente, la manifestación privilegiada o el último refugio del sentido. Como las formas preceden y rodean el fenómeno humano, el sentido no compromete exclusivamente nuestra actividad parlante. Va hacia el hombre y viene de él,

Cómo citar: Chazal, G. (2021). Interfaces. Averiguaciones sobre los mundos intermediarios (L. Paláu, trad.). Ciencias Sociales y Educación, 10(19), 223-277. https://doi.org/10.22395/csye.v10n19a9

Traducción realizada por Luis Alfonso Paláu-Castaño del texto de Chazal (2002).

Agradecemos a la editorial francesa Champ Vallon poner a disposición este material para su divulgación pedagógica en otros idiomas. Nota del editor.

Recibido: 14 de octubre de 2020.

Aprobado: 15 de enero de 2021. 
lo que hace de cada individuo un foco donde se concentra y desde donde se irradia. Los objetos de la naturaleza tienen en sí mismos un sentido que capturamos o no en la medida en que no son un puro caos, sino que se organizan según leyes y en estructuras que las ciencias nos enseñan a reconocer y a describir cada vez más. Hay un orden objetivo del mundo que nos rodea, en el que evolucionamos al actuar sobre él y en el que aprehendemos las formas en que somos capaces de transformarlo. El sentido transita por metamorfosis. Los signos, los símbolos y el lenguaje mismo son formas encarnadas en una materia sonora o escritural. Requerimos abandonar la extraordinaria vanidad que ha podido conducirnos a creer que el orden solo resulta de una proyección de nuestro espíritu sobre las cosas mismas, dado que solo nos podemos apropiar de estas a través de un impulso perceptivo, un esfuerzo mental o un marco conceptual. El orden de las cosas y de nuestro entendimiento se interfieren sin que, por ello, el uno engendre al otro. Sin embargo, nos queda el poder ya bien extraordinario e inagotable de modificar, entre ciertos límites y con ciertas obligaciones, ese orden que nos es dado, ese poder de crear nuevas formas. No nos ocultamos: en nuestro proceder existe un eco de las tesis de Aristóteles; podríamos haber tenido un peor maestro. Sin embargo, no se trata de regresar pura y simplemente a Aristóteles. Entre las intuiciones aristotélicas que construyen el concepto de causa formal y la utilización que puede hacerse hoy de la noción de forma, existe toda la sedimentación del conocimiento de las cosas y de su dominio, la laboriosa historia de las ciencias y de las técnicas, que fueron realizadas de cantidades de revisiones y de revoluciones, y toda la vida de las teorías. Se han desarrollado teorías matemáticas cada vez más poderosas y finas que permiten acercarse y dar cuenta de las formas y de su morfogénesis. El esfuerzo de abstracción científica y la búsqueda constante de esquemas explicativos y eficaces han podido conducir a algunos verdaderos olvidos de la forma, digamos del espacio y de la geometría, en provecho de una expresión formal, abstracta y algebraica en la que una de sus más importantes etapas es la geometría analítica tal y como fue fundada por Descartes. Se ha requerido tiempo y esfuerzos para darle asidero conceptual y matemático a formas espaciales desprendidas de toda métrica ${ }^{1}$. Se ha necesitado probablemente esta escapada por fuera del espacio común para recapturarlo mejor. Este desvío por los signos y los símbolos dotados de potentes operadores era inevitable, pero nos equivocaríamos si nos detuviéramos a reposar aquí. Como todo saber, la filosofía soporta mal que uno se detenga y se instale en algunas certidumbres definitivas. Asimismo, los avances más recientes de las matemáticas, el estudio de los sistemas dinámicos en la geometría fractal de Mandelbrot y la topología renuevan nuestra aprensión rigurosa del espacio y de las formas que lo habitan, las cuales están dadas en la naturaleza o son impuestas al mundo por el despliegue de nuestra

Se puede referir a la obra de Gilles-Gaston Granger (1999), El Pensamiento del espacio. 
actividad. Esta sedimentación milenaria de los saberes desde la antigua física de Aristóteles no le quita nada a la riqueza que aún procura un desvío por la lectura de las obras del estagirita.

El retorno al concepto de forma, como sustituto o equivalente del sentido o de la significación, nos impone dos cosas. En la primera se puede releer a Aristóteles con una mirada renovada, como lo ha hecho, por ejemplo, el matemático René Thom. Se trata evidentemente, y somos conscientes de ello, de hacer historia de la filosofía de una manera insólita y poco respetuosa. Sin embargo, le solicitamos a los filósofos del pasado que nos aclaren nuestro presente, incluso si a veces hacemos de ello interpretaciones un poco bruscas y audaces. Por ejemplo, la lectura de Aristóteles, practicada de modo que integre las adquisiciones de la ciencia, conduce a privilegiar el hilemorfismo, es decir, la inmanencia de las formas a una materialidad que las limita tanto como las trabaja. En la segunda, la búsqueda de sentido exige una investigación sobre las diferentes manifestaciones de la forma a través de las ciencias y de las técnicas. Hemos entablado antes esta indagación en una obrita titulada Formas, figuras, realidad (Chazal, 2011). Estamos perfectamente conscientes del carácter extremadamente parcial de ese trabajo. Por ello, experimentamos la necesidad de proseguirlo. Evidentemente, existen las formas que nos están dadas, pues no descubrimos el mundo físico que nos rodea como un montón informe de materia, sino teniendo organizaciones más o menos complejas. El mineral se cristaliza según geometrías simples; la planta crece siguiendo una morfogénesis a menudo provisional; el animal ejecuta un plan programado que desarrolla una estructura más compleja. Sin las formas estables, al menos unas pocas y provisionalmente, todo se desvanecería en un flujo de deterioro. Por muy breve que sea nuestra vida, le es necesario a su existencia la permanencia de una forma individual que resista algunos breves años a ese flujo. Existen también las formas que les imponemos a las cosas a través de nuestra actividad creadora y fabricante. El incesante flujo que nos proveen los sentidos se organiza, a su vez, por su fuente exterior y por nuestra actividad neuronal. Esta actividad, como tienden a probarlo los aportes más recientes de las neurociencias, tiene en sí misma una de las formas más complejas que pueda encontrarse: la de nuestra materia cerebral.

De nuestro primer trabajo emergían cuatro consecuencias. El trabajo que sigue es una de ellas.

En primer lugar, toda forma está dada en una materia. Aristóteles ya lo había afirmado rotundamente. No existe real ni actualmente ninguna materia prima o fundamental desprovista de forma, a no ser en los mitos de génesis que se abren sobre el caos primitivo. Recíprocamente, la forma es siempre de 
una materia que ha sido trabajada. Toda cosa nace de esta recíproca presencia. La materia y la forma actúan la una sobre la otra y se constriñen mutuamente; no se puede pensar que cualquier materialidad puede tomar cualquier forma, como tampoco cualquier forma puede encarnarse en cualquier materia. Toda morfogénesis se lleva a cabo con libertad vigilada. Existen leyes que rigen las relaciones de la forma con la materia, que la ciencia debe develar y formular lo más rigurosamente posible. La necesidad de esas leyes puede revelarse más o menos rígida según los sectores de realidad: fallas de azar se abren aquí o allá; hay plasticidades que permiten variantes y variaciones. No solamente resulta de ello la infinita diversidad de las formas naturales, sino también la evolución permanente del viviente. En el hombre, esas fallas, esos márgenes de indeterminación han alcanzado el punto que le permite a la inteligencia sustituir al instinto y a la adquisición cultural, perfeccionar la herencia genética. No dejaremos de estar atentos a estos desvíos, para no llamarlos aberturas, puesto que ahí están los espacios de elección y de libertad humana, así como el único fundamento posible de una perspectiva ética.

En segundo lugar, siguiendo la bella analogía del sello y de la cera propuesta por Aristóteles, algunas formas pueden migrar y ser transferidas de una materia a otra al seguir procedimientos y poner en funcionamiento herramientas que respetan las leyes que acabamos de evocar. Estas migraciones, que tienen que ver con evoluciones naturales cuasi mecánicas o procederes voluntarios y humanos, suponen que algunas formas poseen un poder informador, esto es, que existe una dinámica de las formas. Es así como las especies vivientes desenvuelven en individuos, de generación en generación, su programa genético. Así es como el trabajador elabora los bienes de los que tenemos necesidad por astucia y por violencia sobre la materia. Asimismo ocurre con el artista que da nacimiento a formas plásticas o musicales capaces de entrar en resonancia con las formas íntimas de nuestra sensibilidad. No queremos evocar algunas misteriosas potencias inmateriales, algunas fuerzas subterráneas que operan en las cosas y los seres, sino que desearíamos develar las posibilidades de una tal transferencia y sus mecanismos. Importa para el filósofo - ¿será la filosofía otra cosa? - comprender cómo el hombre, que es una forma individual y específica, se muestra capaz de crear nuevas formas. Una tarea, entre otras, es saber cómo el cerebro representa físicamente el mundo tal como la percepción nos lo entrega, y cómo esta representación conduce los individuos humanos a una actividad coordinada y adaptada al medio. En este dominio, el filósofo deberá hacer el esfuerzo de ponerse a la escucha de los aportes del estudio de los sistemas dinámicos, además de aquellos que las neurociencias proveen.

En tercer lugar, y para concretarnos más precisamente en el objeto de este trabajo, la noción de forma convoca otra noción que el vocabulario de la infor- 
mática ha antepuesto: se trata de la noción de interfaz. El término designa en informática todo dispositivo, logicial "programa" o material que asegura la transferencia de la información de una parte del sistema a otra, o de un sistema a otro. En particular, por el sesgo de módulos electrónicos calificados de interfaces, la unidad central de un computador entra en contacto con diferentes periféricos. Se trata también de los módulos logiciales que aseguran la comunicación entre un utilizador humano y una máquina. Fundamentalmente, lo que transita por una interfaz es información. Nuestro propósito es generalizar esta noción a todo lo que asegura la comunicación informadora, la migración de las formas. Somos conscientes de que, en esta generalización, estamos abriendo un campo de investigación inmenso. La primera interfaz que usamos, la más inmediata, es biológica y, culturalmente, nuestros sentidos abiertos al exterior son nuestra piel. Es biológica porque a través de aquellos y de esta entramos en contacto con el mundo exterior y sacamos de él las informaciones esenciales para nuestra sobrevivencia; del mismo modo que en la superficie de nuestro organismo se pueden leer las manifestaciones de la vida interna. La piel es el lugar más importante de la excitación y la reacción, así como de los intercambios intensos, no solamente de energía, sino también de información entre el organismo y su medio. Es cultural porque en todo tiempo y en todo lugar los hombres han utilizado su apariencia para comunicarse: la piel y los decorados que ella puede soportar, así como los vestidos y los accesorios. Los adornos de todo tipo, las pinturas corporales, los tatuajes y las escarificaciones deberán atraer nuestra atención en un primer momento. A la vez límite o borde, lugar de paso de lo externo hacia lo interno y recíprocamente, la piel como frontera posee de manera paradigmática las características de una interfaz natural trabajada por la cultura. Sin embargo, el ser humano multiplicó las mediaciones tanto para informar al mundo como para informarse de ese mundo. Para aprender, comprender y transformar es preciso asumir el destino. Vamos pues a estudiar todos los dispositivos técnicos puestos en funcionamiento en el trabajo industrial, artesanal, las técnicas, las artes, la vida económica y social. No es suficiente con reconocer que las cosas nos han sido dadas a través de estructuras y de formas; no siempre es suficiente con descubrir y tratar de comprender el dinamismo de ciertas formas y su poder de transformación. ¿Cómo una forma puede engendrar otra parecida o nueva? Aristóteles respondía parcialmente a esta pregunta por la analogía del sello y la impronta que acabamos de evocar. El sello lleva una imagen en relieve y puede, por un simple contacto apoyado sobre la cera, transmitir esa imagen sin perder nada de ella. Así, la forma pasa del bronce a la cera. Es esta analogía la que querríamos desarrollar; desearíamos hacerla salir del marco de la imagen literaria, darle una textura científica o, si hay en esto demasiada pretensión, integrarla en una perspectiva filosófica. 
Por ejemplo, en torno a estas nociones de formas y de interfaces se anudan las cuestiones de la comunicación interhumana y de la formación de una intersubjetividad. Solo somos seres sociales por y a través de los artificios y los artefactos. Como al mismo tiempo pertenecemos y no pertenecemos al mundo natural, la interfaz es una necesidad. Esta es necesaria para la supervivencia de la especie que, contrariamente a las especies animales, no puede nunca coincidir plenamente ni con su medio ni consigo mismo. Nuestra presencia a las cosas y a los otros nunca es inmediata ni directa; tenemos siempre necesidad de intermediarios. No vivimos hundidos en nuestro medio, sino que debemos volvernos dueños de él; a la vez debemos distinguirlo como otra cosa y hacerlo nuestro, esto es, plegarlo a nuestro uso. Sin esto seríamos rápidamente aplastados. De la misma manera, tampoco podemos vivir solos; la especie humana es, desde los orígenes, una especie gregaria. Estas comunidades se elaboran sobre relaciones complejas entre los individuos, pero esas relaciones tampoco pueden sostenerse en la pura presencia del otro. Ahí todavía se revelan como necesarios numerosos intermediarios a través de los cuales se elaboran los lazos sociales. Ciertamente, acá abordamos el problema de los mensajes que no cesamos de intercambiar con nuestros semejantes. Por ello, es importante la interrogación sobre el signo, el símbolo y el lenguaje. Incluso si nos hemos negado a reducir el sentido al lenguaje, podemos todavía aclarar su uso desde el punto de vista que consiste en considerarlo como una interfaz típicamente humana que está constituida en los márgenes de la naturaleza y de la cultura, de lo espontáneo y de lo elaborado, de lo innato y de lo adquirido. Sin embargo, tener en cuenta la constitución de las comunidades humanas conduce a muchas otras cosas. El extraordinario desarrollo de los instrumentos de comunicación, el acortamiento de las distancias y la constitución de un universo virtual están en el primer rango de las preocupaciones inducidas por estas cuestiones. Los mensajes que habían escapado a la evanescencia, fijándose para ello en la escritura sobre piedra y papel, han encontrado nuevos soportes que los aligeran y trastruecan su transmisión o su conservación. Por lo demás, pondremos cuidado en no olvidar otras interfaces: la propiedad y la moneda (Aristóteles, antes de Proudhon y Marx, había analizado ya sus funciones), el arte en todas sus formas y el derecho.

Vamos a emprender, entonces, una investigación sobre estos intermediarios. Incluso si el único punto en común de esos intermediarios es el hecho de que aseguren enlaces que permiten transitar las formas y constituirse, tanto su generalidad como su omnipresencia hacen que merezcan que uno se detenga en ellos y que uno busque, quizás bajo su diversidad, alguna naturaleza en común. Hemos tratado de reagrupar bajo el término interfaces múltiples y diversos hechos que van desde nuestro cuerpo instrumentalizado y representado, hasta las máquinas de todo tipo, pasando por los signos, los símbolos y las herramientas. La interfaz es lo que se desliza entre dos elementos para 
conectarlos, ponerlos en relación, hacerlos interactuar y modificarlos profundamente integrándolos en un todo al que ellos se someten. Este término, que nos viene del universo técnico en el que se designa todo dispositivo que permita el intercambio de información entre dos sistemas, estará en el corazón de esta reflexión.

\section{El cueppo interfaz}

La tradición filosófica nos presenta a menudo una imagen de nosotros mismos desgarrada entre el sujeto que somos y el universo que nos rodea, entre una incomunicable interioridad cuya riqueza se exalta y una exterioridad en la que corremos el riesgo de echarnos a perder. Nos referimos, por una parte, a nuestro sentimiento interno y a la conciencia de nuestros estados mentales, sentimientos, emociones, deseos y voluntades; por otra parte, a los objetos con los que nos confrontamos, utilizamos y nos apropiamos. Estamos, para cualquiera que nos observe, en una perpetua interacción con nuestro medio que adapta sin cesar nuestros comportamientos a sus modificaciones. ¿Dualidad real o dualidad ilusoria? Por nuestro cuerpo pertenecemos al universo de los objetos. Y cuando queremos separarnos de ese mundo de las cosas, debemos reivindicar desesperadamente el estatuto de un espíritu o de un psiquismo, esto es, de un sujeto por fuera del mundo o que busca continuamente escapársele. Desesperadamente, pues nada es más huidizo que ese espíritu que el filósofo nunca llega a agarrar definitivamente en las trampas de conceptos claros e inteligibles. ¿Y si sólo tuviéramos un cuerpo? iBella economía ontológica con la que no cesa de regocijarse el materialista! ¿Pero cómo pensar una materia pensante? Aristóteles hacía del alma la forma del cuerpo; Spinoza hacía del espíritu la idea del cuerpo; cada uno a su manera impuso un monismo virulento a los dualismos recurrentes. Estas son rudas filosofías que rechazan el reposo de equilibrio entre los dos términos de la dualidad. Si rechazamos el pensamiento perezoso que separa el espíritu de la materialidad física del cuerpo para concederle alguna beatífica tranquilidad, deberemos volver a poner el pensamiento en el cuerpo y ligar en una totalidad frágil lo que siglos de espiritualismo se han empecinado en desligar. Desde entonces, lo que se volverá central en la búsqueda que emprendemos será el vínculo en el que se reabsorben los dos polos del objeto y del sujeto, de lo interno y de lo externo, de lo mismo y de lo otro. La cuestión que nos preocupa es la de la frontera y del margen, el territorio en el que el cuerpo dice el espíritu y en el que el espíritu se exterioriza en el cuerpo: inseparables.

Es una abstracción hecha de los estados mentales, los pensamientos, los deseos y los sentimientos, de todo lo que se dice que tiene que ver con un puro espíritu improbable. Nuestro cuerpo en sí mismo es considerado como el de los animales, se presenta siempre bajo la forma dual de un interior y de un exterior: 
las vísceras, los órganos, la fisiología subterránea, por un lado, y la piel por el otro. Esta es una nueva dualidad que toma el relevo de la primera y subrepticiamente la reintroduce. Sin embargo, si una vez más rechazamos el recorte dual y las concepciones esquizomorfas, deberemos colocarnos en la frontera, en los bordes, en las márgenes para mostrar su extensión y su importancia. Nuestra piel, nuestra envoltura exterior, nuestra apariencia es una interfaz a doble título. Por una parte, constituye la frontera entre lo interno y lo externo, entre los órganos y el medio; pero también es el lugar de los intercambios incesantes entre el organismo y el mundo exterior. Y nuestra tesis es que los intercambios nos constituyen mucho más que ninguna sustancia individual fija. $\mathrm{O}$ más bien: no hay sustancia sino por el intercambio. No somos un fenotipo que se desarrolla siguiendo el programa inscrito en nuestro genotipo —iun dualismo más!_, sino una forma creada en y por los procesos de intercambio en la que se entrecruzan y se confunden el sí y el otro. No es que neguemos el papel del genoma, del ADN portador de un programa genético, sino que ese papel no es posible sino por la exterioridad del medio en el cual el programa se ejecuta. Nuestra piel participa del proceso de asimilación y del proceso de excreción; es un intercambio de doble sentido. Por otra parte, ella aparece en nuestras relaciones con el mundo y con los otros como la interfaz entre lo interno, el pensamiento o el espíritu y lo externo, el universo de las cosas, de los vivientes, de los hombres. Ella es el punto del derrumbamiento de los dualismos primitivos. En efecto, es a través de ella que los otros nos perciben, a través de ella nos manifestamos. Se equivocan un tanto los poetas que han comparado los ojos a ventanas, como si el alma atisbase detrás de un vidrio, o los labios fueran una puerta que se cierra o acoge. La imagen es estereotipada, quizás, pero tiene su parte de verdad. La máscara del teatro griego no hacía sino retomar, al modo del juego y de la dramaturgia, esta evidencia cotidiana: somos legibles en la apariencia de nuestro cuerpo porque nuestro espíritu es nuestro cuerpo, incluso si esta lectura exige algún aprendizaje y un desciframiento.

Henos pues a nosotros mismos, en nuestra materialidad aparente, constituidos en una doble interfaz: interfaz fisiológica, del órgano oculto a la manera de aparecer, y el interfaz somatopsicológico.

La primera de estas interfaces es desde hace tiempos explotada por el médico que busca leer en el cuerpo, en su superficie, los desarreglos, las carencias, los disfuncionamientos que afectan los mecanismos internos y ocultos. Lo que oculta, encierra y protege también revela lo que se encuentra así disimulado. La piel, su tinte, flexibilidad o, por el contrario, su rugosidad, el color del ojo y el carácter del gesto se vuelven para el médico otros tantos signos reveladores del estado del cuerpo en general. Toda la historia de la medicina testimonia esta función de interfaz y de la utilización que se ha hecho de ella, y que aún 
se hace, puesto que es ahí, en los márgenes del cuerpo propio, donde vienen a inscribirse los síntomas. Seguramente, luego vendrán análisis más finos a completar esta lectura. Pero todavía acá se tratará siempre de ir hacia las técnicas que minimicen las efracciones y permanezcan lo más cerca del envoltorio exterior, del estetoscopio de las modernas técnicas de imagenología médica. No desarrollaremos este primer aspecto. Nos contentaremos con señalarlo y con remitir al lector a los finos análisis que François Dagognet, médico y filósofo, ha efectuado en este dominio ${ }^{2}$. El psicólogo también puede tratar de leer en la piel los movimientos del espíritu, tratar de captar el pensamiento en las apariencias reveladoras de esta delgada frontera que es la piel. Pero nos queremos interesar en otro aspecto de las cosas. Nos ocuparemos en el uso del cuerpo como interfaz entre nosotros y los otros, entre nosotros y la imagen que queremos dar de lo que somos. Pondremos de relieve lo concerniente a la mímica, pero también a la pintura corporal, el tatuaje, las escarificaciones, el maquillaje. Percibiremos aquí el cuidado del rito como el de la estética, la obra del mito y la del arte.

\section{El cuerpo pintado, ser y aparecer}

Como interfaz entre nuestro sentimiento interno y la mirada de los otros, nuestra apariencia inmediata - la de nuestra piel y de sus accesorios, vestidos, maquillaje, peinado, diversos cuidados corporales- se encuentra en el corazón del juego sutil del ser y del aparecer al que la filosofía se ha dejado arrastrar tan a menudo, condenando a veces en un afán ascético, al segundo en provecho del primero. En efecto, lo más frecuentemente se ha opuesto el uno al otro como lo esencial a lo superficial, lo profundo a lo fútil, la verdad a la mentira. El verbo acicalar "farder», que designa el conjunto de las técnicas que buscan valorizar el rostro por medio del empleo de afeites "fards", acaso no está embarcado en la expresión "disfrazar la verdad" "farder la verité». Designa entonces todas las astucias que una voluntad engañadora pone a funcionar para ocultar la verdad, inducir al error y extraviar al que debe ser víctima de las apariencias de una realidad falsificada. Si es verdad que los artificios del aspecto que podemos usar a veces buscan ocultar nuestro ser profundo, nuestros sentimientos verdaderos, así como los desgastes de la edad, en ocasiones también son una manera de decir los signos reveladores del ser verdadero. Trataremos pues de rehabilitar las artes del cuerpo.

\footnotetext{
Ver François Dagognet (1986). Ver en particular el capítulo III "Para una historia de la medicina" de Faces, surfaces, interfaces [Caras, superficies, interfaces] (Dagonet, 1982). También se recomienda consultar Le corps multiple et un [El Cuerpo múltiple y uno] (Dagonet, 1992); Corps réfléchis [Cuerpo reflejado] (Dagonet, 1989a), en particular el capítulo I, "Ce que la clinique nous a appris" ["Lo que la clínica nos enseñó"] (al final de este capítulo apartes de dicho texto); La peau découverte [La Piel descubierta] (Dagonet, 1993). Estos textos fueron traducidos por Luis Alfonso Paláu-Castaño (2006, 2007a, 2007b, 2009). Regresaremos al final de este capítulo sobre la filosofía del cuerpo de François Dagognet.
} 
En el Discurso sobre el origen y los fundamentos de la desigualdad entre los hombres, Rousseau (1999) hace del paso del ser, como inmediata presencia a sí mismo bajo la mirada del otro, una caída, un equivalente antropológico del pecado original. Los hombres se reconocen como semejantes y a partir de allí comienzan a compararse los unos con los otros. Interviene el amor propio. Todo el mal viene de allí. Nadie puede contentarse con lo que es en ese juego de espejo, y cada uno le debe aparecer al otro como superior. Por supuesto, el tener del primero es: "El primero que habiendo cercado un terreno, se apresuró a decir: 'esto es mío'". Pues es por la propiedad que uno comienza a medirse. Las cosas se vuelven los primeros mediadores entre los individuos de la especie humana, la primera interfaz (y sobre ella volveremos). Sin embargo, excepto que supongamos un estado de escasez de los bienes de los que los individuos tienen una necesidad vital, la cosa poseída no es suficiente para arrastrar al hombre del ser al aparecer, pasando para ello por el tener. Es necesario un comercio más asiduo, reagrupamientos en pueblos o en tribus.

Cada cual empezó a mirar a los demás y a querer ser mirado él mismo, y la estimación pública tuvo un precio. Aquel que mejor cantaba o bailaba, o el más hermoso, el más fuerte, el más diestro o el más elocuente, fue el más considerado; y éste fue el primer paso hacia la desigualdad y hacia el vicio al mismo tiempo. De estas primeras preferencias nacieron, por una parte, la vanidad y el desprecio; por otro, la vergüenza y la envidia, y la fermentación causada por esta nueva levadura produjo al fin compuestos fatales para la felicidad y la inocencia. (Rousseau, 1999)

El paso del ser al aparecer constituye claramente una caída, pues a partir de acá, para parecer más o mejor, no se dudará en agrandar la distancia entre lo que se es y lo que uno parece ser. La era de la desigualdad que se instaura es también la de la mentira. Se requerirá parecer más bello, más fuerte, más inteligente de lo que se es y, sobre todo, de lo que no son los otros. Para ello, se hacen astucias de todo tipo: los adornos, las joyas, los coloretes e, incluso, a nivel del lenguaje, la retórica. Esta metafísica roussoniana converge en una antigua idea de la filosofía que conlleva una cierta interpretación del platonismo. Se trata de la que desprecia el cuerpo en provecho del espíritu, que apuesta por el segundo contra el primero. Pues el cuerpo y sus aderezos pertenece decididamente a lo que la mirada del otro capta, a nuestra parte de animalidad que uno quiere reducir y a la que esa mirada nos reduce siempre. El espíritu que uno opone al cuerpo constituye lo esencial, pero permanece inaccesible al examen primero, inmediato y forzosamente superficial. Sócrates, figura fundadora de nuestra filosofía, ¿no es el más bello espíritu en un cuerpo deforme?

Querríamos afirmar la idea contraria. Ante todo, no hay ser que no se revele en alguna aparición. La apariencia revela tanto como engaña; se necesita saberla leer. El proverbio que dice que el hábito no hace al monje es, por lo menos, dema- 
siado simple, por no decir simplista, pues el hábito nos informa claramente antes de disfrazar. No puede haber comunicación de un hombre con otro sin alguna forma, alguna apariencia o alguna interfaz que revele el primero al segundo y viceversa. Una pura interioridad estaría clausurada sobre sí misma, y a fin de cuentas lo único que encerraría sería el vacío. Sin embargo, nuestra piel desnuda, nuestros gestos y nuestras mímicas son aún interfaces demasiado pobres. Los hombres se han dedicado a enriquecerlas. Allí donde Rousseau veía una caída hacia la desigualdad, la mentira y el vicio, nosotros abogaremos porque se ponga de relieve un esfuerzo de comunicación, de exposición, una tensión alegre hacia un excedente de ser, de intercambio y de comunicación. A través de esta comunicación y exposición la sociedad se constituye en tanto que tal.

Que el cuerpo y más particularmente la piel puedan identificar y revelar, es la idea que quería promover la fisiognomonía y la frenología. Para esta última, se trataba de leer la naturaleza profunda del individuo en los volúmenes del cráneo y en los rasgos de la cara. iLa apariencia no puede mentir! Se ha denunciado abundantemente los excesos de esta craneoscopia y de la filosofía subyacente. No deseamos reactualizarla para justificar inmundas cacerías a las facies. No pensamos tampoco que el vicio o el crimen estén inscritos fatalmente por algún pesado determinismo en las fisonomías. Nuestro carácter, aún menos nuestra historia individual, no son legibles a priori en las formas de nuestra cabeza o en el relieve de nuestro rostro. Es más, antes de condenar las lecturas de lo psíquico sobre la superficie del organismo para el uso que de ello se hizo, sería necesario releer de más cerca la obra de Lavater como lo ha hecho François Dagognet (1982) ${ }^{3}$. Se encontrarían allí más matices y menos determinismo de lo que se ha querido decir con frecuencia. Contrariamente a Gall, Lavater nos previene contra las ojeadas rápidas. Si lo psíquico y sus evoluciones se reflejan en la cara, es necesario aún aprender la lectura de sus marcas y de sus trazas, descubrir las armonías y las desarmonías significativas. Sin embargo, tras el exceso, permanece una parte de verdad. "Gall reconoce voluntario que ellos tienen en común [con Lavater] buscar conocer el interior por su exterior, lo moral por lo físico, encarando el organismo humano como una especie de lengua escrita por la naturaleza misma" (Lantéri-Laura, 1970, p. 86). No encajaremos el paso a las críticas de la frenología desarrolladas por Hegel (1939, pp. 268-282), Maine de Biran (Tisserand, 1924, pp. 67-86) o Schopenhauer (1912, pp. 135-136). La frenología continuaba hasta el error y la exageración las primeras tentativas de medida del cráneo de Camper, Daubenton o Blumenbach. La inclinación del cuello permitirá distinguir cuantitativamente la bipedia. Aún hoy, el antropólogo vuelve a trazar por medio de las medidas de los ángulos del cráneo la historia de nuestros ancestros. Y la localización cerebral que ella supone - por errónea que fuesen las de

En lo concerniente a la frenología, uno se puede dirigir a la obra Histoire de la phrénologie de Georges LanteriLaura (1970). 
Gall y Spurzheim - abrirá la vía a los trabajos de Broca que los últimos frenólogos, como Bouillaud, trataron de enrolar en sus filas. Es verdad, sin embargo, que la victoria de los localizadores sobre los unitarios no es la de la frenología. La historia ha retenido, sobre todo de los trabajos de Gall y de Spurzheim, la obra anatómica y quizás la idea de que las facultades mentales encontraban una localización en la corteza. Si la craneología es hoy, en el mejor de los casos, una fantasía no científica, y en el peor de ellos charlatanismo peligroso, no es menos cierto que al lado de la fisiognomonía ella constituye una tentativa de semiología que busca leer la realidad humana en la apariencia corporal y, por tanto, una rehabilitación de la apariencia. Ahora bien, la tesis que queremos defender aquí es la del cuerpo significante, el cuerpo que se cubre de signos haciéndose signo. Más allá de los yerros pseudocientíficos de los frenólogos, querríamos explorar esta significancia del cuerpo y de su apariencia. En 1862, en momentos en que la moda frenológica se extingue, Alphonse Bertillon propone un método de identificación de los criminales fundamentado en las medidas del cuerpo: el "sistema antropométrico". El señalamiento de un individuo es cuantificable y personal; se medirá la cabeza, la oreja derecha, el pie izquierdo y la longitud de los dedos. Sin embargo, se está todavía en un dominio demasiado abstracto donde la precisión milimétrica no es suficiente para garantizar que un solo individuo corresponda a una sola serie de medidas. La altura de la cabeza, la longitud del pie o la de los dedos remite aún al esqueleto, al armazón interno y oculto. Pero por este hecho son abstracciones. Es necesario retomar, o al menos completar, el procedimiento de identificación por medio de los elementos superficiales, inmediatamente aparentes. Por lo demás, el policía debe poder reconocer al criminal con la primera mirada; no siempre tiene los medios de efectuar largas y minuciosas mediciones. Las fichas de Bertillon serán completadas con informaciones relativas al color de los ojos o de los cabellos. Se les adjuntará rápidamente fotografías (las famosas fotografías de frente y de perfil de los registros judiciales); una vez más se insiste en la importancia de la apariencia. Pero es hacia la envoltura exterior, hacia la piel, que uno debe girarse si se quiere una segura identificación. Allá, en la superficie más externa del cuerpo, cada uno lleva ínfimos surcos que componen dibujos siempre diferentes de un individuo al otro. Y más que en la superficie, es en las extremidades mismas del cuerpo que esos dibujos deben ser detectados y observados: en la punta de los dedos. En su obra Fingerprint, Francis Galton (1892) hace el elogio de la huella digital conrespecto a las medidas antropométricas de Bertillon. Conocimos luego cuál fue el uso que la criminología ha hecho de la recolección de huellas digitales luego de las primeras utilizaciones de un sistema cercano al de Galton por parte de la policía argentina, sistema debido a Juan Vucetich. Nuestra piel lleva la firma o la marca de nuestra individualidad. Incluso herida profundamente, cuando la piel se reconstituye en el extremo de nuestros dedos, 
reproduce los mismos dibujos. Estos parecen resistir tanto a los traumatismos como al envejecimiento. Solo estamos a un paso de considerar aquello como su carácter esencial. El individuo se individualiza en sus partes más superficiales. El filósofo no dejará de reconocer la manifestación del ser en el aparecer que se confunden, en lo superficial, en lo inmediatamente perceptible. Pero el dibujo de las huellas digitales es natural, nos está dado, no podemos ni negarlo ni transformarlo. Una filosofía, por poco naturalista que sea, no se ofuscará con su papel de revelador y de criterio de identificación. ¿Pero qué decir de los dibujos que serán pintados, para no mencionar los definitivamente grabados (el tatuaje) al término de un acto voluntario del que los lleva? ¿No pueden ellos engañar tanto como revelar? Ya no se sostiene en una naturaleza profunda que se impondría al cuerpo, sino a prácticas culturales y locales que están ligadas a épocas y a lugares precisos, indefinidamente cambiantes.

En efecto, la piel desnuda no puede ser suficiente como interfaz entre lo interno y lo externo, es aún demasiado "natural"; se precisará hacer de ella un objeto "cultural". Por sus propias marcas ella solo puede dar identificación. Será pues pintada, tatuada, escarificada. Se le pondrán colores y dibujos. Y el rostro será el primer lugar del intercambio: la boca y la palabra, los ojos y la mirada. Debe decir más de lo que puede o decirlo de otra manera; se lo sustituirá por una máscara para esquematizar y centrarse en un rasgo único. El teatro en sus comienzos, tanto en la Grecia antigua como en el Japón, hará uso de ella con elegancia y finura. Después del rostro, el cuerpo entero será erigido en objeto de rito, en mensaje social o simplemente en obra estética.

La antropología, principalmente por la obra de Claude Lévi-Strauss, nos ha enseñado que lo natural estaba asociado a lo universal, mientras que los comportamientos culturales estaban marcados por lo particular, lo singular, lo local, para no decir: lo único, lo raro, lo exótico o lo extraño. iUn dualismo más qué habrá que superar! Solo la prohibición del incesto tenía un carácter universal y cultural a la vez; cultural puesto que propio de las sociedades humanas ${ }^{4}$; universal puesto que el antropólogo la encuentra en todas las sociedades. Pero esta ley reforzada por su excepción podría muy bien, cuando se encaran las prácticas de pintura del cuerpo, sufrir una nueva excepción. Y nos alegramos con ello puesto que amenaza así este dualismo fácil de lo natural y de lo cultural. Queremos decir con esto que esas prácticas que tienen un carácter indiscutiblemente cultural-y veremos que están ligadas a creencias, a ritos, o incluso simplemente a investigaciones estéticas - son igualmente universales. Por supuesto, en el tiempo y el espacio se encuentran numerosas variantes estéticas y técnicas. Pero la prohibición del

Sin embargo, parece, si le ponemos cuidado a los etólogos, que algunas sociedades animales tengan prácticas de evitación del incesto. 
incesto también está sometida a variantes a través de las diferentes culturas, sociedades, civilizaciones.

Primero, es necesario decir que esas prácticas parecen tan antiguas como las sociedades humanas ${ }^{5}$. Numerosas estatuas o representaciones prehistóricas dan testimonio de ello. Las pinturas rupestres del Sahara - ya se trate de "la fase de las Cabezas Redondas" (7.000-6.000 a. de C.) o del período Bovidiano (5.000-1.500 a. de C.) — comportan personajes cuyo cuerpo está manifiestamente decorado por pinturas o tatuajes, alineamientos de puntos, líneas curvas regulares, etc. Ídolos femeninos neolíticos, a menudo símbolos de la fecundidad, encontrados en Mesopotamia, en los Balcanes o en Europa Central, muestran con frecuencia ora surcos cavados, ora restos de pintura siguiendo formas geométricas que evocan decoraciones corporales. Evidentemente, ignoramos la significación de esos decorados, pero estamos claramente en presencia de la evocación de pinturas corporales o de tatuajes. Las representaciones de Egipto antiguo, como los frescos o las estatuillas femeninas de loza vidriada azul del Imperio Medio, evocan también el maquillaje del rostro, para no mencionar los tatuajes sobre todo el cuerpo. En particular, las estatuillas reencontradas en tumbas y que constituyen probablemente símbolos de fecundidad tienen el sexo vivamente realzado y marcado con motivos que representan quizás tatuajes. Creta, Grecia clásica y Roma conocieron el colorete, como lo testimonian frescos y estatuarias. Las bellas ocultaban sus arrugas y daban más blancura a su rostro y a sus brazos con la ayuda del blanco de plomo; acentuaban con tintes sus labios y sabían resaltar su mirada maquillando sus ojos. Ovidio, cantante de los cuerpos sensuales, hace el elogio de las griegas y de sus senos cuyos "pezones rosados estaban adornados con tintura dorada". Así como el colorete permite ocultar la cercanía de la vejez y paliar la pérdida de las frescuras de la adolescencia, también es el medio de marcar su personalidad y su rango en la sociedad. El teatro griego empujará esta idea al extremo al darle a los actores una máscara que esquematiza su función y su rol. El término francés personne deriva del latín persona, que designaba primero la máscara que llevaba el actor y luego el tipo de personaje asociado a esa máscara. La etimología nos recuerda, a propósito que lo que caracteriza de manera más esencial a un ser humano, es el hecho de que ser una persona está estrechamente ligado a la máscara que revela, como en una caricatura, los rasgos esenciales de un individuo, así como su papel en un drama, una comedia o una tragedia, en una palabra: en una sociedad.

Numerosos elementos nos han sido dados, para esta parte de nuestro trabajo, por la obra dirigida por Gröning (1997), Decorated skin, a world survey of body art, la cual comporta numerosas ilustraciones que hacen de ella no solamente una fuente de reflexión sino también un verdadero objeto estético. También nos podremos remitir a Roy (1957), Arts sauvages [Artes salvajes]. 
La historia más reciente de nuestras sociedades occidentales muestra también que el adorno siempre se ha completado con el uso de los coloretes, y que ese uso continúa. Es verdad que sobre todo el rostro es objeto de los cuidados más permanentes. Sin embargo, el tatuaje nunca ha desaparecido, incluso cuando con frecuencia ha sido atributo de ciertas clases sociales de las más desfavorecidas (marineros, albañiles, simples soldados de los cuerpos más expuestos, elementos del hampa). De hecho, hubo una época en que los condenados debían llevar la marca indeleble de su condena en su carne, sobre su piel (marcada con hierro al rojo). Pero aparece entonces - y esto refuerza nuestra tesis-como un medio de expresión para los que se encuentran privados de otros instrumentos para decir lo que ellos son, piensan, experimentan o simplemente para afirmar su pertenencia a una categoría que la sociedad marginaliza. Se grabará en el cuerpo la marca de esta marginalización en una especie de parodia de la marca del hierro al rojo, con la que la antigua sociedad golpeaba a los presidiarios. Hoy los tatuajes socialmente permitidos deben permanecer discretos y solo revelarse en la intimidad. Sin embargo, algunos no dudaron en adornarse toda la superficie de sus cuerpos para ofrecer públicamente verdaderos cuadros. Los tatuadores organizan ferias y concursos internacionales, como en Francfort-sur-le-Main, para hacer ostentación de su arte y de su técnica. El dibujo tatuado oscila actualmente entre seguir siendo el signo de una cierta marginalidad y acceder al estatuto de la obra de arte. Asimismo, muchas manifestaciones contemporáneas, deportivas, pero también políticas o sindicales, dan lugar a disfraces en los que la pintura del cuerpo interviene. Expone, así, los conflictos reales o interpretados. ¿Acaso no vemos a los hinchas de los clubes deportivos pintarse los colores de su club? Los carnavales siguen siendo momentos de una libertad que se manifiesta a menudo por medio de la fantasía de las máscaras y de los maquillajes. El circo con sus clowns, clown blanco y Augusto institucionalizó verdaderamente el maquillaje y reencontró las reglas y convenciones dignas de las prácticas ligadas a ciertos ritos primitivos.

Finalmente, el arte contemporáneo, en su esfuerzo por el desposeimiento y por la reflexión sobre sus propios orígenes y en su tentativa por captar y valorizar lo efímero, no ha temido volver a la pintura del cuerpo o a la pintura por medio del cuerpo. Elvira Bach, de renombre internacional, pinta directamente el cuerpo de mujeres desnudas que solamente se visten con zapatos de tacones altos.

El body art ha perfeccionado, en torno a Yves Klein y sus antropometrías a fines de los años cincuenta y durante los años sesenta, diferentes técnicas que recurrían al cuerpo entero en el proyecto pictórico. Se harán grabados sobre papel o tejidos de los cuerpos recubiertos de pintura. Las modelos se vuelven pinceles. 
Para interpretar mejor su papel de interfaz, el cuerpo es instrumentalizado, puesto que el cuerpo real se desliza entre el pintor y el cuadro. La desnudez ya no es evocada ni expuesta, sino que se vuelve dinámica en tanto que la producción del cuadro será eventualmente fotografiada. Se duplica así la función de interfaz del cuerpo del modelo. La obra finalmente se reabsorbe en la huella que permanece en la obra bajo esta forma de traza. Habría que citar también el Wiener Aktionismus [Accionismo Vienés] reagrupado en torno a Hermann Nitsch, Otto Mushl y Gunter Brus.

Acabamos de mostrar la universalidad de la pintura corporal en el tiempo, desde los más antiguos trazos humanos hasta nuestras sociedades contemporáneas; mostremos también que esa universalidad se extiende en el espacio. Se encuentran prácticas de pinturas corporales en todos los continentes. Desde las bellas cretenses hasta nuestras modernas elegantes, el maquillaje juega un papel en las relaciones sociales, en todo escenario de seducción. El rango social de una mujer se mide frecuentemente por el arte del maquillaje que ella posee, en los matices que sabe introducir en los usos que comanda la moda, así como el siglo clásico establecía el rango de los hombres por la longitud de sus pelucas. El cuerpo pintado, incluso con en colorete la piel, se confunde con el adorno que marca la fiesta. El carnaval inscribe sobre el cuerpo los juegos de inversiones sociales que él suscita. La máscara prolonga la pintura del rostro. Se trata entonces tanto de ocultar una identidad como de exhibir otra más secreta, más reprimida. Ese doble movimiento de ostentación y de disimulación utiliza el cuerpo como interfaz entre lo que está oculto y lo que se muestra, entre lo que está prohibido y lo que está permitido, entre la razón y el desbordamiento. La fiesta pasa por el cuerpo, pero este solo pude jugar dicho rol al precio de los artificios que se le aplica. En la vida cotidiana actual, una lectura atenta de las revistas de modas muestra cómo el maquillaje sirve tanto para disimular como para exteriorizar su personalidad, y soporta la idea que uno se hace de sí mismo. Tenemos razón en extasiarnos y reír con condescendencia ante las pinturas, los tatuajes y las escarificaciones que utilizan los pueblos alejados y exóticos.

Pero aún hoy, cualquiera que atraviese nuestra familiar Europa no dejará de notar -y quizás hasta se sorprenda con ello- las múltiples maneras como las mujeres se maquillan la cara. Vería que numerosos personajes populares del circo o del teatro ejecutan esos rituales del maquillaje. El cuerpo es una interfaz entre estados internos y el mundo exterior, pero no es suficiente por sí solo, en su desnudez, para representar ese papel expresivo; se precisa pintarlo y aprestarlo.

Acabamos de insistir en prácticas que se dan entre nosotros. La mirada que podemos darles debería ayudarnos a comprender mejor las que encontramos por todas partes en el mundo. América del norte, la de los indios, era 
rica en pinturas corporales significantes. Karl Bodmer y Geroge Catlin nos han dejado su recuerdo en muchísimos retratos. Estas pinturas a menudo están asociadas a acontecimientos sociales importantes (matrimonios, entierros, pero también guerra o paz), a ritos estacionales (danza de las raquetas entre los chippewa, por ejemplo), al rango social y a la pertenencia tribal del individuo que las porta. Allá, como por todas partes, en América del sur, en África, en Oceanía, en Indonesia, en Asia (la India, China y Japón), la pintura corporal y sus formas más radicales, así como los tatuajes y las escarificaciones nunca son prácticas gratuitas. Se integran a rituales religiosos complejos, a normas sociales con frecuencia muy elaboradas. Parece claro que tienen que ver con algún uso fundamental del cuerpo como interfaz, tan fundamental como para encontrárselo por todas partes. Ciertamente, las razones que empujan a que una parisina se maquille en la mañana antes de salir para el trabajo, a que una joven chica berebere se mande a hacer tatuajes o a que las mujeres kaleri de Nigeria estén orgullosas de sus escarificaciones pueden parecer bien diferentes. Son tan diferentes como las razones para pintarse el rostro entre los habitantes de las islas Andaman, entre los actores japoneses del teatro Nô o entre los payasos de nuestros circos occidentales. Incluso, el proceder puede parecer bien distinto en el body painting moderno, en las obras de Yves Klein o de Günter Brus.

Sin embargo, querríamos ahora explorar algunas de esas razones. En este sentido, se busca mostrar que, más allá de las diferencias, hay un mismo proceder que consiste en tomar el cuerpo como interfaz para jugar con su doble estatuto: objeto por su materialidad entre otras materialidades y sujeto humano indefinidamente reconocible como tal.

A la mirada de los otros, no somos nada distinto a nuestro cuerpo: por él nos manifestamos y a través de él no solo nos reconocen como un ser humano en general, sino como individuo situado en un contexto social, en un conjunto humano. Nuestro lenguaje mismo se apoya constantemente en el gesto, la mímica e, incluso, la mueca. Todo el lenguaje en su práctica está rodeado de un aura gestual que hace que los mensajes que transmitimos en dirección a los otros pasen también por nuestro cuerpo considerado globalmente. Si la cultura pule nuestro verbo, nosotros no impediremos el movimiento excitado de nuestros dedos o de nuestras piernas. Nuestro cuerpo siempre nos traiciona. Cuando el hombre pobló el universo de espíritus de todo tipo, también se presentó con su cuerpo en el mundo de los espíritus y de los dioses. Este se vuelve la interfaz entre los dioses y los hombres. De este modo, las pinturas corporales revelan a menudo qué espíritu protector, tutelar o solicitado se siente ligado el individuo y proveen indicaciones sobre la pertenencia sociales, tribales o clánicas, y sobre el linaje. Es un verdadero sistema de signos y de símbolos el que se 
instaura. La información pasa de los hombres a los espíritus, y de los hombres a los hombres por el sesgo de las pinturas corporales. Por este hecho, ellas pertenecen a los ritos sociales y religiosos, y constituyen verdaderos códigos. Indican la posición del individuo en el curso de la vida cuando difieren con la edad y la situación matrimonial. De este modo, entre los mendi de Oceanía, las muchachas reciben un adorno particular cuando se las compromete. Marcan los períodos del año que se conforman con el curso de las estaciones; los indios de Norteamérica, por ejemplo, se ponían de acuerdo sobre sus pinturas en el rostro en relación con las fiestas estacionales. Entre los mursi del suroeste etíope, las escarificaciones en los brazos y el cuerpo indican las proezas del individuo que las lleva. Son una historia individual o social, un mensaje en dirección de los miembros de la sociedad a la que se pertenece o en dirección a los espíritus; las pinturas, los tatuajes y las cicatrices llevan un mensaje. Se podrían multiplicar los ejemplos. El cuerpo se vuelve un manuscrito viviente. Como si el gesto no fuera suficiente, se le añade la coloración del rostro. De ello resulta toda una simbólica de las formas y de los colores que son, por tanto, códigos minuciosos y precisos, sabios y mágicos. Nos equivocaríamos si solo viéramos acá un lenguaje primitivo; frecuentemente es muy elaborado y necesita un largo aprendizaje. Pero es un lenguaje profundamente ligado a la materialidad del cuerpo, pues los colores y sobre todo las formas deben plegarse a las del cuerpo para subrayar ciertas partes y enmascarar otras. Incluso cuando las pinturas tienen que ver con convenciones sociales fuertes, ellas se adaptan a cada individuo y para cada individuo en cada circunstancia de su vida. Entre los dioses y los hombres, entre los hombres y los hombres, la riqueza de la comunicación está ligada a la plasticidad de la interfaz. De ello resultan variaciones infinitas sobre temas recurrentes, así como cada lengua hablada posee una infinidad de acentos y de entonaciones que permiten caracterizar a cada individuo. La interfaz corporal nuca es neutra o simple mediación; actúa sobre el mensaje y sobre su contenido. Escoger entrar en comunicación con los espíritus y los dioses a través de los artificios de los adornos que se le ponen al cuerpo es, al mismo tiempo, definir esos espíritus y esos dioses como seres sensibles a tales aderezos. Nuestro cuerpo es el espejo del otro, pues el otro reconoce su propio cuerpo en el mío. Desde entonces, adornar de figuras y de colores es comenzar a jugar con ese espejo, desviarse en él o de afinar su reflejo. Inscribiéndose en un contexto cultural, cultual y social, el adorno corporal no solamente afecta al individuo a una comunidad, sino también del presente al pasado y de la persona a sus ancestros. El individuo se encuentra ritualmente referido a un linaje y se proyecta en el futuro ${ }^{6}$.

El uso del cuerpo como interfaz responde, entonces, a múltiples funciones. Todas esas funciones, ya sean rituales, religiosas o festivas, que buscan marcar

$6 \quad$ Ver Randall White (2000). 
una pertenencia a clanes, indican una posición en una jerarquía o una función en la distribución social de las tareas y participan de los ritos de iniciación o simplemente en los intercambios cotidianos con nuestros semejantes, tienen necesariamente una dimensión social. Pues si las pinturas corporales, los tatuajes, las escarificaciones, utilizan el cuerpo como interfaz, o más bien exaltan su función primitiva de interfaz, ello supone un proceso de comunicación. Gracias a su decorado de piel, cada quien expone su ser todo entero como individuo y como miembro de una colectividad humana. Contra Rousseau, el ser se manifiesta en el aparecer socialmente controlado. Esto supone desde entonces reglas, normas, cánones. Con respecto a esas normas, se puede desarrollar y mantener un espacio de libertad y de creatividad. Las formas modernas y técnicas de la interfaz en informática, por ejemplo, imponen protocolos de comunicación, es decir, normas según las cuales los mensajes deben ser redactados para franquear esas interfaces. Lo mismo ocurre con el cuerpo interfaz. La interfaz construida según normas impone, de rebote, sus normas a los miembros de la sociedad en la que ella funciona. Por ejemplo, los ritos de iniciación imponen en muchas sociedades prácticas de marcado del cuerpo, pintura y tatuaje; en contrapartida, esas prácticas guían y orientan los ritos en los que participan. Demos otro ejemplo: las pinturas corporales pueden indicar las etapas de la vida y a cada etapa corresponderán dibujos y colores. En ciertas tribus africanas se hacen cicatrices en relieve sobre el cuerpo de las mujeres a todo lo largo de su vida, desde el nacimiento. Cada cicatriz marca una etapa de la vida: primeros menstruos, noviazgos, matrimonio, nacimiento de un hijo, destete del niño... El adorno inscrito en el cuerpo hace la historia de una vida, otro tanto como lo inverso. Al mismo tiempo cuenta y factura la vida individual, y determina la feminidad. Por este hecho, esas cicatrices se vuelven un elemento de seducción y poseen un carácter erótico. Se es una chica o un muchacho, una mujer o un hombre, no solamente porque se posean los órganos de un sexo o del otro, sino también porque se lleva tales o cuales ornamentos de piel, porque se deben tener ciertos ornamentos en un momento importante de la maduración sexual, pero también porque no se tiene el derecho de llevar otros. Negarse a las pinturas, a los tatuajes o a las escarificaciones significa colocarse en una posición marginal por fuera de la definición funcional y estatutaria del hombre y de la mujer.

El papel dinámico de la interfaz, del cuerpo interfaz, es aún más manifiesto cuando los tatuajes, así como en las mujeres bereberes, juegan un papel en la protección de la vida. La interfaz no es solamente un medio de comunicación, sino que la comunicación supone el cierre tanto como la apertura. El intermediario puede prohibir el paso tanto como favorecerlo. Se trata de protegerse de las influencias nefastas por medio de tatuajes. Espíritus malévolos asechan y penetran los cuerpos por la piel y sus poros. Algunos períodos de la vida en los que el cuerpo está débil son particularmente propicios a esas nefastas 
invasiones: la pequeña infancia, la pubertad, el embarazo, el parto. Algunos lugares del cuerpo son también particularmente favorables a las intrusiones porque comportan orificios hacia el interior no disimulados por los vestidos: la boca, la nariz, los ojos. Estos deberán ser marcados particularmente por tatuajes y periódicamente por pinturas de alheña. El cuerpo interfaz debe regular las comunicaciones entre lo interno, en donde reside la identidad profunda, y lo externo amenazador, poblado de fuerzas dispersivas. Lo mismo ocurrirá con las manos con las cuales tocamos el exterior y dejamos nuestra impronta sobre las cosas. También el pie, si está desnudo, abandona "una parte del alma" en la huella que deja en el suelo. Se lo cubrirá, pues, de signos que retendrán emanaciones por las que el mundo interior, la sustancia profunda, podría vaciarse hacia el exterior.

\section{El arte y el cuerpo}

El arte exalta el cuerpo, le da la palabra y lo cubre de líneas pintadas o marcadas más profundamente en la carne. Hemos evocado la manera cómo los artistas, particularmente en el arte moderno, han utilizado el cuerpo ora como soporte, ora como instrumento. Interesémonos ahora en los cuerpos silenciosos, los que la pintura y la escultura han escenificado en sus formas más clásicas. Cuando el pintor muestra el cuerpo sublimado, el cuerpo torturado, el cuerpo exaltado, hace de él la interfaz privilegiada de la emoción, del sentimiento, de la idea. En los cuadros de temas religiosos, mitológicos o históricos, el cuerpo ha sido escenificado en una historia como aquella o simplemente como la expresión de un carácter que se embellece o se zahiere en el retrato; siempre es la representación material y concreta de una idea, de una ideología o simplemente de un estado de espíritu. Vestido o desnudo, siempre da una concepción del hombre. El pintor no va a descuidar la ciencia, sino que se nutrirá de anatomía y, de rebote, la enriquecerá. Entre el arte y el saber del médico, el cuerpo representado es aún una interfaz que querríamos explorar un poco más. La forma corporal proyectada en el espacio del cuadro o en el de tres dimensiones, del bronce o del bloque de mármol, no solo reenvía una imagen mediatizada del cuerpo, sino que participa de la constitución profunda de la interfaz por la cual se comunican lo interno y lo externo. ¿De qué exterioridad y de cuál interioridad se trata en la obra plástica; las nuestras o las de un desdoblamiento en el que participan el artista tanto como el espectador? Recordemos la ambición de los pintores impresionistas que ya no quieren pintar un objeto ni darlo a ver, sino poner en la tela lo que pasa entre el objeto y el pintor. Quieren negar la separación brutal y consumada entre el sujeto y el objeto; quieren colocarse deliberadamente entre lo interno y lo externo, y constituir al cuadro mismo como interfaz. ¿La tarea será más fácil con el paisaje y el monumento que van al encuentro del pintor que abandona su taller, que con el cuerpo humano? El más impresionista de los 
impresionistas, Claude Monet, podría hacernos creer esto, pues hay muy pocos personajes en sus obras. Pero tenemos que poner cuidado en no olvidar al que se encuentra en el nacimiento del movimiento, Eduardo Manet, ni a Bertha Morisot, Augusto Renoir, Edgar Degas. En ellos el cuerpo representado entra en ese doble desdoblamiento en que la obra no presenta el cuerpo en una imagen más o menos transformada o traspuesta, ni el hombre ni la mujer, sino nuestra relación con el uno y con la otra. Por este motivo, la obra plástica se vuelve una interfaz primordial en la que el cuerpo toma un sitio singular. Esta ambición del impresionismo perdurará en sus sucesores.

La primera conquista del hombre es probablemente su propio cuerpo, que no se contentará con vivirlo, sino con representarlo. Pues si el cuerpo es una interfaz, como acabamos de verlo a través de las prácticas que hacen su instrumento de nuestra relación con el mundo, los otros y los dioses, es necesario apropiarse de ese instrumento. Nos interesamos en el proceso por el cual representamos en nuestro cuerpo imágenes en las que él se desdobla. No es suficiente con decir que el cuerpo es un espíritu que se manifiesta, el uno estando en el otro: es menester, además, que el cuerpo se deje ver en actitud de decir. La interfaz supone o entraña un desvío reflexivo que el arte ha sabido asumir. En este sentido, ahora se trata este desvío por la representación plástica.

Se sabe o se supone que las primeras representaciones del hombre, la prehistoria o la Grecia arcaica no tienen que ver únicamente con una función especular neutra, sino que se integran a rituales que deben correlacionar el mundo humano con el de los espíritus o de lo divino. Se supone que las siluetas sobre las paredes de las grutas no buscaban solamente la emergencia de una emoción estética o, si así era, hacía parte de un conjunto cultual, ritual. Más tarde, el templo acoge las formas humanas, primero fijas, y luego poco a poco ganadas por el movimiento detenido. Ellas fijan la devoción. Estas serán prestadas a las divinidades que acercamos a nosotros a través de un cuerpo muy frecuentemente magnificado. La potencia de Zeus será la de una musculatura desarrollada; la sabiduría de Atenea será la gracia altiva de un cuerpo de mujer que la piedad sabrá engalanar. El cuerpo esculpido intercede por nosotros. Parece que la fe no puede subsistir sin cuerpos intermediarios. Ciertamente, siempre ha habido iconoclastas para romper la imagen en provecho de un espíritu puro o purificado. La querella desgarrará la iglesia de Oriente; los que veían en la representación de Cristo un retorno al paganismo resistían a los que recordaban que Dios se había hecho carne y que se había encarnado en un cuerpo humano. En el siglo VIII esta cuestión opondrá al emperador de Bizancio y al papa. Se requirió el concilio de Nicea en el 787 para que fuesen condenados los iconoclastas. Desde entonces la Iglesia, que estigmatizó a veces con tanta violencia el culto de los ídolos de mármol o de bronce, no tardó en poblar sus templos de 
figuras tan humanas de las santas y de los santos junto a la de Cristo mismo. Platón había fustigado al artista que mostraba la divinidad en cuerpos llenos de fuerzas o de gracia. El cristianismo, como buen heredero del neoplatonismo, predicará el desprecio del cuerpo, aunque permanezca en su tradición una recurrente tentación de exaltarlo, incluso cuando es rechazado del lado de la condenación. El arte religioso asegurará ese movimiento por el que la mediación del cuerpo es colocada en el corazón de la piedad. El culto mariano es, en este sentido, particularmente significativo. Ya las letanías de la Virgen no dejan de evocarlo como cuerpo infinitamente respetado y respetable, pero finalmente cuerpo. No solamente ella es llamada madre y virgen (mater Christi, divinae gratiae, purisima, castisima, inviolata, intemerata, amabilis, admirabilis, boni consilii, Virgo prudentissima, veneranda, praedicanda, potens, clemens, fidelis...), sino también vaso (vas spirituale, honorabile, insigne devotionis...). Pues ella se entrega a la devoción con todo su cuerpo de mujer y de flor (rosa mystica); y ese cuerpo es a la vez el de una reina (regina) y el de una mediadora, interfaz privilegiada entre la justicia de Dios y la súplica de los hombres (speculum justiciae). Pero evidentemente es el artista pintor quien toma a la letra el texto del culto mariano para ofrecer la imagen del cuerpo cuyos rasgos serán a veces prestados de la mujer amada o amante. Por ejemplo, se supone que en la célebre Virgen y el Niño rodeados de ángeles rojos (Museo real de las bellas artes, Amberes), Jean Fouquet hizo el retrato de Agnes Sorel en el siglo $\mathrm{XV}$. Como en toda representación de la Virgen, es presentada por su cuerpo de mujer y de madre mezclando en él el simbolismo religioso y el llamado a la emoción y al sentimiento.

En el cuadro de Jean Fouquet que acabamos de mostrar, tanto el vestido como los brazos se abren, uno para dar el seno y alimentar al niño, el otro para acoger el recogimiento de la piedad. Un cuerpo, como interfaz, debe estar abierto o cerrado, replegarse para dejar de jugar ese papel o, al contrario, ofrecerse para establecer el vínculo entre lo humano y lo divino. Contra el menosprecio del cuerpo - y sobre todo el de la mujer - el cristianismo ha predicado, por lo demás, que las vírgenes sensuales del arte religioso tratan de elevar el espíritu hacia Dios a través de ese mismo cuerpo ${ }^{7}$. No terminaremos de ponderar representaciones religiosas que recurren al cuerpo como interfaz entre una debilidad humana vivida y una divinidad supuesta, compensadora y consoladora. Es particularmente notable que la religión, que ha abrigado el mayor número de teologías despreciadoras de la carne a la que hay que bien frecuentemente humillar, desarrolle la exaltación del cuerpo mediador a veces hasta la obsesión. En el corazón mismo de la teofanía cristiana, Cristo es ante todo un cuerpo,

No puedo dejar de decir que una de las representaciones de la Virgen María más voluptuosas y encantadoras que haya que conocer es Notre Dame de París; me parece más encantadora que las carnudas Madonnas italianas... Nota del traductor. 
un dios que se ha hecho carne y que rescata a la humanidad con el sacrificio de su carne. La figura de Cristo como cuerpo martirizado, entregado a la consumación bajo las especies del pan y del vino, pone en el centro de la práctica ritual el cuerpo interfaz. El contacto directo que los místicos piensan mantener con Dios en el éxtasis es igualmente una práctica inscrita en el cuerpo, y a menudo la unión con Dios es vivida como una unión carnal. En el Cantar de los cantares (la más sensual expresión de los cuerpos amantes del corpus bíblico), desde la más profunda exaltación del espíritu contra el cuerpo, isan Bernardo decide comentar! Se comprende que el arte occidental, judeocristiano, pueda entonces desplegar las evocaciones pláticas del cuerpo tanto como cualquier otro arte. El cuerpo negado o desvalorizado se eleva, sin embargo, al rango de símbolo; se encuentra petrificado por una significación que no cesa de exudar.

Antes de abandonar el arte religioso, y como intermediario inevitable, no podemos dejar de detenernos algunos instantes en las numerosas pinturas de María Magdalena, cuyas más conocidas son ciertamente las de Georges de La Tour, quien declinó el tema en muchas ocasiones. El personaje es probablemente la amalgama de diferentes actores de los evangelios, la hermana de Marta y María, la prostituta que baña en perfume los pies de Cristo y luego los enjuga con sus largos cabellos desatados. El personaje está nimbado de sensual ambigüedad. Es un mediador equívoco, pues La Tour hace emerger de la sombra un cuerpo de mujer pleno de belleza meditativa. En este sentido, es un interfaz entre nuestros deseos eróticos profundos y el deseo de una serenidad por fin perdonada. El cuerpo de María Magdalena ha reunido a la santa y a la prostituta, lo sagrado y lo profano. ¿Será aún esta María Magdalena la que, en el Evangelio de san Juan, a la hora de la resurrección, descubre a Cristo? (Reina Valera, 1960, Juan 20:1). "iNo me toques!"”, le dirá entonces Jesús, como si el misterio mismo de la resurrección implicara una nueva relación con el cuerpo. ¿Es este cuerpo transfigurado el que visita las miradas Georges de La Tour en las María Magdalenas? El tema será retomado frecuentemente por pintores que probablemente están fascinados por esta profunda ambigüedad, aunque pocos serán los que podrán salvaguardarla. Por ejemplo, la Magdalena penitente de Paul Baudry (1858) nos da la imagen de una mujer semidesnuda en la que triunfa el cuerpo. Lo sagrado solo es recordado por una discreta cruz colocada en su mano.

Que el arte abandone el terreno religioso, se laicice, se gire hacia los temas tomados de una mitología olvidada, que llegue al retrato, a la exaltación de escenas heroicas o a la representación de personajes socialmente importantes, cualquiera sea pues el tema, se trata de permitir ver el cuerpo. La interfaz se diversifica. Otras ideas, otras emociones, otros sentimientos le son confiadas

Mi traducción dice: "Deja ya de tocarme, porque aún no he subido al Padre" (Nacar-Colunga, 1962, Juan, 20:17, pp. 1127-1128). 
para ser dichas, transmitidas y develadas. Se puede creer que cuando el cuadro ya no presenta el cuerpo como interfaz entre la humana piedad y el cielo, es porque ha hecho de él un objeto en sí. Por ejemplo, la historia del arte no dejará de poner de relieve en las escenas de mitología galante del siglo XVIII, en un François Boucher, un simple pretexto para exponer el cuerpo femenino en sensuales situaciones. Parece que toda idea de mediación se borra y que el cuerpo mostrado deja de ser un intermediario para volverse el puro objeto de una emoción estética al desnudo. Sin embargo, nos equivocaríamos si nos detuviéramos en esta primera impresión. Si bien es cierto que ya no se trata de alcanzar alguna trascendencia a través de las representaciones del cuerpo, no por ello deja de ser cierta una comunicación que, por ser más subterránea, no deja de estar en el corazón mismo del acto de contemplación de esas obras. Si hay un movimiento en la mirada que damos al cuadro, puede que ya no vaya de nosotros a Dios, pero sí de nosotros a nosotros. Los cuerpos expuestos, por ejemplo, en Diana saliendo del baño de Boucher, nos ponen en presencia de nuestra propia sensualidad, de nuestros propios deseos, de nuestros propios fantasmas, lo que permite que permanezcan secretos a la vez que sean dichos. La interfaz del cuerpo es entonces entre nosotros y nuestros sueños. De acá nace probablemente el placer estético ligeramente turbado que rodea a este tipo de obra. Por lo demás, las cosas pueden volverse mucho más explícitas, como en el cuadro de Fragonard intitulado el Cerrojo que, sin ceder a la vulgaridad, expone de manera sorda el acto sexual evocado tanto por la pausa de los personajes abrazados, en el lecho que espera en la sombra otros embates, y la mano que a plena luz pasa el cerrojo sobre el secreto de alcoba. Desnudo o vestido, el cuerpo no cesa de reenviar la imagen de nuestros secretos placeres, develamiento sin riesgo de las partes profundas de nuestra vida.

Asimismo, el cuerpo presentado por el arte, en el retrato o en diversas escenas heroicas y conmemorativas, retoma de forma más explícita su papel de interfaz. Se tratará ora de exaltar un momento de la historia (escenas de batallas o de pactos y tratados), ora de embellecer un personaje importante (los numerosísimos retratos de los grandes), ora más modestamente de exponer la vida cotidiana en sus mínimos aparatos (la pintura holandesa de Vermeer, de Hooch, Hals y Steen). En todos los casos, el cuadro asegura en los cuerpos la mediación indispensable entre el espectador y la sociedad en un lugar y en un tiempo dados, bien sean reales o míticos. El cuerpo pintado hace de nosotros testigos, se intercala entre lo real y la percepción que de él tenemos. Indica, atrae la atención y nos remite a nuestros gestos, nuestras ideas, nuestros miedos, nuestros entusiasmos, nuestras pasiones y nuestras heridas. Juega el papel de una lupa, le da una mayor agudeza a nuestra mirada, aguza nuestra percepción. Incluso en las escenas más modestas, por el juego de las formas y de la luz, pone de relieve la parte universal que comporta cada singularidad. Ciertamente, hay 
algo de verdadero en la definición que Kant da de lo bello como universal sin concepto. El cuerpo en el cuadro es claramente la interfaz que trata de abrirnos al universal humano o por lo menos a un universal humano posible y encarable, incluso si nunca se lo ha alcanzado. La humilde lechera, los anónimos rostros de Vermeer, los cuerpos desnudos de las mitologías galantes, las figuras simbólicas de la Apoteosis de Henri IV y La proclamación de la regencia de Rubens, hasta los cuerpos torturados de Guernica de Picasso y los cuerpos que bailan de Matisse, en todos ellos se trata siempre del paso de lo singular a lo universal. Y el cuerpo humano, el cuerpo vivido, amado y expuesto es la inagotable interfaz que asegura ese pasaje por la virtud constante de la emoción o del deseo.

Sin embargo, nos equivocaríamos si permaneciéramos, en cuanto a la obra de arte, en esa plaza de mediación en torno a la que se construye la emoción estética. El cuerpo interfaz en las artes plásticas también juega un rol en la aprehensión científica que podemos tener de nosotros mismos. Asimismo, la anatomía se descubre a través de la obra pictórica y escultórica o, más bien, la anatomía y las artes plásticas mantienen constantes relaciones de intercambios en los que el cuerpo toma una dimensión de interfaz.

El propio médico es consciente de un paralelismo y de una comunidad de enfoque con el artista. Por ejemplo, Henri E. Sigerist (1960) escribe:

El pintor de arte clásico compone sus cuadros de una manera lineal, plana, uniforme y clara, mientras que el artista barroco libera por todas partes el movimiento, su obra gana así en pintoresquismo y en relieve. Se rompe la forma armoniosa, la uniformidad se vuelve multiplicidad, los rasgos se detienen, anegados en los juegos de sombras y luces. Dos maneras completamente diferentes de ver la naturaleza... Harvey es pues el primer médico que encarnó las ideas del barroco. Fue quien expresó en medicina el nuevo ideal y las nuevas concepciones. Es anatomista y, en el cuerpo, no ve la forma sino el movimiento. Sus investigaciones no parten de la configuración del corazón, sino del pulso y de la respiración, es decir de dos movimientos elementales que sólo se detienen con la muerte. (pp. 190-191)

He aquí un puente explícito entre medicina y representación pictórica del cuerpo. Es este puente el que debemos evocar ahora.

La disposición interna de los huesos y los músculos, las articulaciones y las interacciones determinan la forma externa. La apariencia los revela tanto como se apoya en ellos. Tanto el pintor como el escultor que quieren exponer el cuerpo están obligados naturalmente, como por una necesidad estética, hacia la anatomía. Se interesan en la exploración médica del cuerpo. Testigo de ello es, por ejemplo, la célebre Lección de anatomía del profesor Tulp de Rembrandt (1632). Y hay más: el artista se hará anatomista ${ }^{9}$, frecuentará el gimnasio y

El caso de Leonardo da Vinci es particularmente significativo de esta preocupación anatómica de los pintores del Renacimiento. Cfr. Pour la Science (2000). 
luego las salas de disección. Notará precisamente las inserciones musculares, los ángulos formados por las articulaciones óseas, los volúmenes más secretos que la piel deja apenas aparecer, pero que contribuyen a las formas generales del cuerpo. No se trata solamente de ganar una fiel reproducción de las formas más o menos idealizadas, sino también de traducir los movimientos más suaves y los más frenéticos en la fría inmovilidad del bronce, del mármol o en la superficie de la tela. Esto no solo implica conocer las disposiciones en el espacio del esqueleto y de la musculatura, sino saber cómo esos diferentes elementos juegan los unos con respecto a los otros. A la captación de la forma se le superpone el conocimiento de la función que la representación no separa.

En primer lugar, el arte emprende una conquista de lo real. Sin embargo, como el cuerpo representado no es sino una interfaz que permite ir más allá de la realidad, asegurar el paso de lo real a la imagen, así como garantizar y mantener una abertura entre el objeto real y su representación, se requerirá, sobre la base de la verdad anatómica, que el artista se entregue aún a múltiples deformaciones. El cuerpo deberá, ora exaltarse en sensuales opulencias, ora descarnarse o desarticularse, sin que el artista cese de referirse a los corpus de anatomía. Se pasa siempre, entre la anatomía y el arte, de una elemental descripción del cuerpo a una idea del cuerpo.

Ni las imágenes más antiguas del cuerpo humano, las pinturas rupestres, las esculturas de diosas-madres ni las Venus prehistóricas buscan manifiestamente una estricta fidelidad a la realidad. Evocan más de lo que representan. No se trata tanto de dar una visión realista del cuerpo, del hombre o de la mujer, sino de valorizar ciertas funciones, meterlas en exergo o solicitarlas. Aquí se exalta la fecundidad, allá uno se reconcilia con las fuerzas favorables a la caza o a la guerra. Este primado de la función sobre la fidelidad a la forma anatómica perdura a lo largo de la historia del arte. En el arte románico, por ejemplo, las leyes de la perspectiva no determinan la talla de los personajes sino su importancia. Cristo será siempre más grande que los que lo rodean. La anatomía de la representación puede estar dirigida por consideraciones políticas, religiosas, ideológicas. La estatuaria consagra a la mujer a la maternidad valorizando su vientre, y los pliegues de las telas acentúan este proceso ${ }^{10}$. Por ello, François Dagognet (1982) puede escribir: "Cuando el artista representa la mujer, especialmente la Virgen, este 'expresionismo' intenso que es el estilo románico la consagra implacablemente a la maternidad."

El cuerpo concebido como interfaz entre los deseos de los hombres y la potencia de los dioses o de algunas fuerzas ocultas se preocupa poco por la anatomía. Habrá que esperar el arte egipcio, pero sobre todo el arte griego, para que la

10 Nos podemos reportar a los análisis de André Scobeltzine, retomados y comentados por François Dagognet (1982). 
preocupación anatómica entre en la economía de la elaboración de un cuerpo representado como mediador. El templo expresa una exigencia de fidelidad a lo real a la vez que de idealidad. Por lo demás, los comienzos están aún lejos de ese ideal de un cuerpo al mismo tiempo realista y perfecto. La musculatura está poco marcada y la postura está fija en una simetría convenida. Las simetrías naturales, las de los ojos y de los miembros, son valorizadas. El cuerpo se repite a un lado y otro de un eje vertical. Sin embargo, el artista toma en cuenta algunas proporciones entre el tamaño de la cabeza y el del cuerpo, entre la longitud de los brazos y la de las piernas, etc. El número como proporción gana la imagen del cuerpo en la que el artista toma conciencia de que el cuerpo también es el lugar de una armonía numéricamente expresable. En la conquista de la anatomía por el arte reencontraremos esta idea de proporción y de razón que se encuentra en toda definición de la interfaz. La interfaz supone una medida. Reposa sobre la puesta en correspondencia de valores, lo que aún Aristóteles llamará la analogía. Si la imagen que el arte ofrece es un analogon del objeto representado, también es preciso comprenderlo en este sentido. Suponemos que la función de interfaz (en este caso de la imagen corporal) reposa sobre un fondo de proporción de la que no dejaremos de encontrar una expresión matemática.

La historia de la estatuaria griega es particularmente ejemplar de esta conquista de proporciones ideales al mismo tiempo que de una fidelidad cada vez más precisa a la anatomía. Los músculos aparecen correctamente colocados sobre el esqueleto y conectados a su función en el movimiento. Estarán más o menos inflados la postura cuando imponga contracción o relajamiento. La estática de las primeras estatuas de kouroi cede su lugar a la dinámica de un movimiento fijado en su realización. Una pierna avanza, un brazo se levanta, otro retrocede. Los problemas de proporción ganan el respeto del equilibrio. La simetría vertical deja lugar a un conjuntos de líneas dispuestas en triángulos. La forma expresa el movimiento. La imagen del cuerpo persigue, a través de la historia del arte griego hasta el período helenístico, esta búsqueda de una "verdad" de la representación. El artista, incluso si aún está privado de las enseñanzas de la disección, accede directamente a la anatomía frecuentando el gimnasio y la palestra donde se entrenan los atletas desnudos. En esos lugares de observación privilegiada se elabora poco a poco un corpus de reglas anatómicas en la medida en que ellas deben dar cuenta de la realidad, y reglas estéticas puesto que van dirigidas a la mano del escultor. Estamos pues en este espacio intermediario entre creación y descripción, entre el arte y el saber. La observación conduce a una verdadera teorización que describirá el cuerpo ideal. Esas reglas serán reunidas así en un canon como el que se le atribuye a Polícletes. Esos cánones se vuelven verdaderos tratados de anatomía para uso de los artistas. Lo que esos cánones quieren enseñarnos es una anatomía ideal, armoniosa y limitada por proporciones medidas. Pitágoras habita la anatomía 
naciente en la expresión estética. Lo feo, lo deforme y lo desproporcionado son expulsados resueltamente. Si aparecen en el período helenístico, son el atributo de los seres inferiores, malos, perniciosos, gentes del pueblo despreciadas, sátiros o enemigos de la patria. Sin embargo, el uso de esos cánones producirá las más bellas obras maestras de los últimos siglos de la Grecia antigua. Testigo de ello es, por ejemplo, la Venus de Milo conservada en el Louvre, cuyos finos detalles musculares de los brazos, la espalda y del vientre participan de la realización estética.

El arte románico regresará a una forma de expresionismo en el que el ideal religioso prima sobre el respeto de la anatomía. Hemos mostrado cómo el cuerpo juega entonces un rol considerable en la mediación de la imagen entre el hombre y lo sagrado. Sin embargo, el Renacimiento retomará la tradición helénica. El pintor y el escultor frecuentan el gabinete de anatomía. El cuerpo y los gestos son detallados de manera casi clínica. Se regresa también a los cánones que prescriben las proporciones que se le deben dar a las diferentes partes del cuerpo (entre el tronco, la pelvis, la cabeza, los brazos y las piernas). Las diferencias entre el niño y el adulto, entre el hombre y la mujer, comienzan a contar. El regreso al desnudo, que la Edad Media había abandonado (con algunas raras excepciones), corresponde a una atención renovada del artista por las formas externas e internas del cuerpo. No se puede permanecer en las simples apariencias, sino que se requiere conocer las estructuras internas y la disposición de los órganos en profundidad para explicar por medio de la imagen las formas exteriores. El cuerpo oculto se revela en el cuerpo visible. Los movimientos del corazón no son una simple metáfora. La vida interna se manifiesta exteriormente. Para captarla, el pintor debe conocer la organización más secreta del cuerpo. A veces el movimiento que conduce al pintor hacia la anatomía y la fisiología - se conoce, por ejemplo, estudios anatómicos de Leonardo da Vinci-se invierte y el anatomista recurre al pintor. Se pretende así que el De corporis humani fabrica libri septem de Andreas Vesalio (1514-1564), una de las primeras obras de referencia de la anatomía moderna, está ilustrada con imágenes provenientes del taller del Tiziano en Venecia.

Sin embargo, el cuerpo de la escultura griega y de la pintura del Renacimiento sigue estando estático incluso cuando el movimiento es evocado por la disposición de los elementos anatómicos perfectamente capturados y dispuestos. El arte barroco rompería, como lo sugiere la cita de Sigerist que hemos hecho, esta representación lisa y serena. La pintura y la escultura de los cuerpos se ponen siempre de acuerdo con las concepciones dominantes en anatomía. ¿Existe una sorda correspondencia entre el artista y el científico? ¿Y cuál sería su fundamento? ¿El barroco que expresa con el pliegue y el repliegue al movimiento mismo inspira — como lo sugiere Sigerist—una nueva anatomía, 
la de Harvey? Decir que lo uno inspira lo otro probablemente tenga que ver con una concepción extrema. Nos parece más simple pensar que el paralelismo entre el arte y el saber del cuerpo — que filósofos de la medicina como Georges Canguilhem y François Dagognet no han dejado de subrayar - tiene que ver con una concepción común del cuerpo. Existen correspondencias entre los estudios científicos de los médicos, los anatomistas y la expresión pública de una visión dominante del cuerpo humano en una época y en un lugar dados.

Sin embargo, el artista está agarrado entre los constreñimientos de su respeto por la anatomía y su deseo de utilizar el cuerpo como interfaz entre él y los otros, entre la idea y su representación material. Con frecuencia el rostro no es suficiente para decir el amor, el odio, el respeto, la cólera o el miedo. Todo el cuerpo debe participar en la violencia de los mensajes, los sentimientos y las pasiones. Se encuentra deformado de muchas maneras, plegado, descuartizado, y las reglas de la anatomía deben borrarse ante la expresión. El cuerpo representado, más aún que el cuerpo real, exterioriza estados interiores. Virgilio reporta en la Eneida la leyenda de Laocoonte, el sacerdote troyano al que las serpientes mataron con sus dos hijos. El terror y el combate no han dejado de inspirar las artes plásticas. Existe una estatua de inspiración helenística del primer siglo antes de Jesucristo que se conserva en el Vaticano. En esta, a pesar de la violencia escenificada, la anatomía de los personajes está minuciosamente respetada. El anatomista reconocerá los deltoides, el bíceps braquial, el tríceps, el pectoral, el músculo grande serrato o los cuádriceps correctamente posicionados. Aunque al tratamiento que se hace de la leyenda no le falta énfasis, se permanece en un respeto estricto de las leyes de la anatomía. El mismo tema será tratado mucho más tarde por el Greco en un cuadro conservado en la Galería Nacional de Arte de Washington. Los cuerpos se retuercen en una composición circular. Las proporciones de los antiguos cánones ya no se respetan. Los músculos del brazo de uno de los personajes ya no corresponden al deltoides, una rodilla deforme hace una articulación minimizada con respecto a la musculatura de la pierna. A la pelvis de una extraña mujer desnuda que se mantiene a la derecha del cuadro le falta relieve, incluso presenta algo de masculino, mientras que sus trapecios están exageradamente alargados. Las deformidades del cuerpo, menospreciando las reglas de la anatomía, exaltan el carácter trágico del episodio de la epopeya troyana. Puesto que evocamos la pintura del Greco, no dejaremos de recordar el hecho bien conocido de que él estira sistemáticamente hacia arriba los rostros alargados de sus personajes hasta el límite de lo verosímil. A veces se le ha atribuido esta característica a un defecto de visión del pintor. Por lo demás, poco importa. No deja de ser cierto que en la obra de este pintor todo nos atrae, mirada y espíritu, hacia arriba. Los cuerpos se deforman en una aspiración tendida y vertical, toman por este hecho un carácter casi místico como si la falta anatómica quisiera redimir las 
faltas morales de una humanidad llena de religiosidad. La función de interfaz desarticula los cuerpos.

El artista puede, entonces, cometer errores anatómicos a propósito hasta destruir deliberadamente la organización corporal. Se trata de manifestar prioritariamente la sensualidad de los cuerpos femeninos principalmente. Las asperezas musculares son borradas; otros detalles demasiado realistas son eliminados: la vellosidad pubiana, por no decir el sexo femenino mismo, se atenúa por ser demasiado carnal. Así se va manifiestamente del Renacimiento italiano y de la escuela de Fontainebleau hasta el siglo XIX académico. Sin embargo, el pintor conserva en su exaltación del cuerpo una sólida base anatómica, y con frecuencia se mantiene al tanto de los progresos de la medicina. Permanece un fondo realista de fidelidad al cuerpo real. Si el cuerpo es alisado, si lo que tendría que ver demasiado con una impúdica vulgaridad es eliminado, los marcos de la anatomía envuelven aún el esfuerzo de la representación pictórica. En el siglo XIX, Ingres irá más lejos. Se trata de escenificar las líneas armoniosas de las que el cuerpo solo es un pretexto; se vuelve la interfaz de una emoción estética que es necesario ganar, incluso al precio del realismo anatómico, que el pintor ya no duda en sacrificar. El cuerpo desnudo de la mujer es el teatro privilegiado de una "extraña cirugía estética", para retomar una expresión que usa Jerónimo Coignard en un artículo consagrado a ese pintor en la revista Beaux-Arts (n. ${ }^{\circ} 133$, abril de 1995). Vértebras supernumerarias alargan la columna vertebral de La gran odalisca. Este alargamiento se acentúa por el escamoteo del pliegue glúteo, mientras que la pierna izquierda se levanta tras la derecha como desprendida del resto del cuerpo. Privada de la articulación del tobillo, sufre de una pateta que atrofia el talón. La bañista de Valpinçons sufre de la misma desaparición del pliegue nalgatorio que acentúa un rebajamiento de los hoyuelos. Otros cuadros del mismo pintor estiran el cuello y lo dotan de un bocio que evita toda rotura de las curvas en su impulso. Además, como en La bañista de medio cuerpo, la juntura del seno está desplazada para el lado del cuerpo.

Sabemos que Picasso retomará, a veces de forma sistemática, estos retuerces de la anatomía para plegar el cuerpo a funciones estéticas. Sin embargo, en Ingres la carne adquiere en estas manipulaciones anatómicas una extraña suavidad, una dulce plenitud y una agradable languidez. El pintor no ignora la anatomía. Muy por el contrario, si la conoce es para traicionarla mejor en provecho de una búsqueda de las formas ideales. Pues el cuerpo ya no es sino el instrumento de esta búsqueda, la mediación hacia una pureza de las curvas queridas como intercesión emocional. Una vez evacuado el interés por la fidelidad a lo real, el cuerpo retoma plenamente esa función de interfaz entre nuestra percepción y nuestros sentimientos, lo que permite hacer resonar en nosotros alguna intuición de lo bello. 
El impresionismo disolverá aún el cuerpo y lo evocará más de lo que lo representa. El objeto que el cuadro toma de la realidad ya no vale por sí mismo. La percepción es su cualidad subjetiva que debe manifestarse. Entonces, más que en otra parte quizás, cuando el cuerpo entra en una composición pictórica —pensamos en Las bañistas de Renoir, por ejemplo— no es sino la interfaz evanescente de nuestras "impresiones" profundas. También esto pasa con el puntillismo:

veremos cómo los cuerpos se van fundiendo poco a poco con el fondo, captado en el instante en que amenaza con reabsorberse en el decorado como Las presumidas de Georges Seurat.

La anatomía garantiza aún un reconocimiento, pero este pasa a un segundo plano. De esta manera, la investigación se emancipa de una pureza estética donde incluso la forma y sus curvas deben dejar sitio al evanescente temblor de los colores que se arriman y se depositan uno cerca al otro sin nunca fundirse, pero que se responden todos en una resonancia global.

Paralelamente, la anatomía puede revelarse o disolverse en un juego de colores y de luz, así como encontrarse transfigurada en un respeto escrupuloso de sus más íntimos detalles. Con la escuela realista y su más notable representante, Gustave Courbet, la manera más realista y más cruda eleva la descripción anatómica al nivel del arte. El origen del mundo de Gustave Courbet (1866) presenta a una mujer cuya cabeza se oculta — como si la expresión de un sentimiento legible en una mirada o el pliegue de una boca hubiera podido desviar la atención de ese cuerpo expuesto- desnuda, las piernas abiertas y mostrando su sexo. Aunque nos encontramos ante una verdadera plancha de anatomía genital en la que está presente hasta el más mínimo pelo pubiano y el menor repliegue de las carnes, la obra posee una extraordinaria fuerza estética. No tiene que ver ni con el diccionario médico ni con la intención pornográfica; está ahí, en sí misma, como una evidencia estética en la que el cuerpo tan crudamente develado golpea con fuerza la sensibilidad del espectador. La imagen nos pone en presencia de nuestra más secreta intimidad. Estamos lejos de los cuerpos casi asexuados del arte clásico o académico y, sin embargo, permanece la misma función de interfaz en la obtención de la emoción estética.

El arte del siglo XX no dejará de confrontar el cuerpo con las más sistemáticas deformaciones, las más extrañas metamorfosis y las dislocaciones más geométricas. Parece que se consuma un divorcio entre el arte y la anatomía. El cubismo con Braque y Picasso es analítico, es decir, descompone indefinidamente las formas. Luego es sintético, es decir, las recompone en una estructura nueva y significativa. Este aspecto es particularmente ejemplar de este nuevo tratamiento que debe sufrir el cuerpo humano para ganar un papel eminente en 
la expresión pictórica. La preocupación anatómica es despedida. Las naturales curvas de los músculos son reemplazadas por líneas angulosas. La posición de los miembros, unos con respecto a los otros, ya no es sino aproximativa. Las reglas de la perspectiva, que ya Manet o van Gogh habían abandonado un tanto, son definitivamente dejadas de lado. Un regreso a formas de arte más primitivas ("el arte negro", por ejemplo, pero también el arte románico y gótico del medioevo europeo) muestran que ellas no tienen el carácter universal que se les quiso conferir desde el Renacimiento. Se podrá pintar todos los elementos del rostro, los dos ojos, la nariz y la boca, en el mismo plano para evocar un perfil sobre una cara y despreciar la disposición de esos elementos en el espacio real. Grandes superficies coloreadas borran los volúmenes. Contra la verdad engañosa e ilusoria de las tres dimensiones figuradas en el cuadro, se regresa a la verdad de una tela plana. La forma, un momento a punto de desaparecer en el impresionismo y captada en su desvanecimiento luminoso, o aun totalmente perdida en provecho de un simbolismo de los colores como en Kandinsky, regresa, pero considerablemente depurada, desprovista de relieve, que es la tercera dimensión del espacio deliberadamente doblada sobre el plano. Un brazo, un seno, unas caderas y una articulación se reabsorben en algunos trazos como en las famosas Demoiselles de Avignon de Picasso. La suavidad de la piel y sus maridajes matizados con las texturas de las telas dejan el campo libre a la representación de los cuerpos dolorosos y torturados, o bien revelan en una fría luz sus misterios íntimos.

Pero el cubismo y otras experiencias que, aunque rechazan la abstracción pura, dislocan los cuerpos ¿habrán roto con toda preocupación anatómica? Necesitamos responder claramente que no y ello por dos razones al menos. Primero, esas escuelas se mantienen siempre más acá de una basculación en el arte abstracto, donde se pierde toda evocación de la realidad. Todas las deformaciones y dislocaciones que el cuerpo debe sufrir no deben impedir que él continúe siendo reconocible. Para que conserve su papel de interfaz debemos aún reconocernos en la imagen que nos es presentada. Las formas puestas en operación deben poderse referir por algunas sugestiones al menos a la anatomía real. Incluso el Desnudo bajando una escalera de Duchamp se conforma con la anatomía de un movimiento que él sugiere e impone. El saber que la medicina engendró, como la sombra de Étienne-Jules Marey, pesa aún sobre la construcción del cuadro. La depuración y la deconstrucción del cuerpo mantienen un reconocimiento siempre posible. Si los miembros se dispersan sobre la tela, entran en composiciones nuevas o juegan papeles extraños, son aún en su forma de brazo o pierna, nalga o mano.

La segunda razón por la que la representación del cuerpo en la pintura moderna conserva un lazo, por tenue que se lo quiera, es necesario y, con 
la anatomía, nos parece aún más profunda e importante. Se trata, entonces, de la verdad. Las leyes del realismo y de la perspectiva han podido parecer durante un tiempo las reglas de toda verdad de la representación. ¿ Pero no se trata de elevar al rango de verdadero lo que en el fondo no era sino artificio? La verdad de la representación clásica no es la de la anatomía, sino la de una mirada o de un punto de vista. Al cambiar la mirada y el punto de vista, la pintura moderna muestra que hay una verdad más allá de la verdad primera de la percepción inmediata, más allá de la representación conmemorativa o mnemónica. Lo que se viola no es tanto la anatomía (un rostro posee claramente dos ojos, dos orejas, y un cuerpo dos brazos, dos piernas), sino las reglas de una percepción que nos prohíbe la visión simultánea de dos ojos sobre un solo perfil. La representación del cuerpo que nos entrega la pintura moderna no es patológica o, si lo es, tiene que ver con una normalidad bien artificial nacida en el Renacimiento. Se reencuentra una lógica y otras normalidades que no dejan de recordar la plancha de anatomía que presenta los órganos, no tanto tal y como ellos se encuentran, sino de suerte que uno pueda verlos mejor. Pensamos por supuesto en los "desollados", que con clara frecuencia se burlan de las leyes de la perspectiva. El cuadro cubista, que descompone los cuerpos en elementos geométricos y los recompone de otros modos, los hace hablar. No nos alejamos de lo real, sino que lo penetramos mejor y, en este sentido, el pintor retoma el proceder de Étienne-Jules Marey que descomponía el movimiento para captar mejor su naturaleza. Suben a la superficie de la tela las violencias hundidas, los deseos y los desórdenes secretos. El cuerpo es entonces interfaz ideal que hace que oscile lo interno, lo que está enmascarado o subyacente en el dominio de lo visible. Por supuesto que no se le pedirá al pintor la precisión o la objetividad que constituyen el ideal del enfoque científico. El arte y la ciencia no nos dicen la misma cosa sobre el cuerpo y es claro que lo usan de forma diferente. Sin embargo, tanto para el uno como para el otro se trata claramente de ir más allá de las primeras apariencias.

Nos hemos demorado en la representación pictórica del cuerpo, pero lo que hemos dicho valdría también para la coreografía. El ballet hace evolucionar los cuerpos en el espacio de la escena y el tiempo del espectáculo, mientras que en el cuadro, por poco que cuente una historia, el tiempo, antes y después, pasado y futuro, debe condensarse en la eternidad de un instante fijado sobre el lienzo. En uno y otro arte el cuerpo se vuelve interfaz del tiempo, ofrece la materialidad en la que el chorreo se solidifica. El ballet deja aún escapar — pero la música que lo acompaña también - una parte de temporalidad en la organización rítmica de los movimientos. El ballet se encamina hacia su fin, inexorablemente. La imagen pictórica o escultural debe decir el tiempo en el espacio. Este papel le está destinado al cuerpo representado. Con frecuencia, los paisajes no tienen historia salvo si comportan las marcas del hombre bajo forma de alguna 
artificialidad o de algunas obras humanas. Es el cuerpo en su movimiento detenido el que dice el tiempo. Por ejemplo, en el cuadro de Fragonard que ya hemos presentado se mantiene todo un pasado preparatorio en los cuerpos de los amantes que se estrechan el uno contra el otro; se evoca todo un futuro de placer y de voluptuosidad por medio de una fingida reticencia y por la mano que, a ciegas, pasa el cerrojo sobre una intimidad a punto de constituirse. De manera gráfica, el tiempo es evocado por el juego de equilibrio y de desequilibrio de las formas corporales. La pierna derecha de la mujer en la prolongación del brazo del hombre traza la diagonal de una caída que compensa el triángulo colocado sobre su base, que se forma por las dos piernas del hombre. Los cuerpos así situados entre estabilidad y desequilibrio, entre consentimiento y resistencia, nos hacen pasar de un antes a un después que uno puede imaginar, pero se ausentan del instante captado por el pintor. La anatomía no es pues la simple yuxtaposición de los órganos; en sus formas ella capta sus relaciones, su función. La forma, la apariencia que conserva en el primer plano el pintor, incluso el color, se revelan inseparables de los movimientos, para no mencionar la fisiología subyacente.

Sin embargo, el cuerpo representado no jugaría plenamente su papel de mediador, e incluso de multimediador, si permaneciera en el cuadro y no llamase al espectador a participar de la obra de arte. El personaje representado debe entrar en relación con otros personajes. Se puede tratar ante todo de las relaciones que mantienen los sujetos pintados en la escenificación en la que ocupan su lugar. François Dagognet (1982) analizó los sutiles lazos de comunicación que pueden establecerse ${ }^{11}$. Pero no vayamos a olvidar los vínculos que se establecen con el espectador; han resultado buenos escándalos de ello. $\mathrm{O}$ el cuerpo representado mira para otro lado como prosiguiendo una vida que nos sigue siendo ajena, en una historia que no es la nuestra, y entonces quedamos colocados en posición de mirones. O bien el personaje nos mira y de manera muda se dirige a nosotros con más o menos fuerza. Detengámonos algunos instantes sobre la naturaleza de este lazo que se teje entre el cuerpo fijo de la tela y el espectador que ante ella se detiene un momento. Escogeríamos dos ejemplos — quizás extremos, pero significativos desde ese punto de vista- de cada uno de los dos casos evocados.

El primer ejemplo es que el personaje pintado nos mire; el asunto solo es soportable si esa mirada no nos implica demasiado. ¿La mujer desnuda del Almuerzo en la hierba de Manet habría producido tanto escándalo si mirara a otra parte y no en nuestra dirección? Sería también ingenuamente provocadora. Su mirada tranquila casi que invita a tomar asiento en el cuadro, y entonces el burgués se molestará. Reaccionará gritando que qué escándalo y qué horror, por medio de la diatriba y la burla, pues es necesario ocultar bien aquel fastidio.

11 Ver la primera página y media del anexo 3, hasta el final de la cita de Freud (nota del traductor). 
Con la Olimpia, también de Manet, se encuentra el mismo fenómeno. Se dijo que el cuadro era escandaloso por ser demasiado realista, excesivamente impúdico, poco liso. Sin embargo, no era la primera vez que un pintor se arriesgaba a pintar una cortesana, incluso si le daba el nombre de alguna voluptuosa divinidad. Por lo demás, habrá que reconocer que el cuadro de Manet retoma célebres cuadros que lo han precedido (la Venus de Giorgione, por ejemplo). El problema es, más bien, que todo el cuerpo de Olimpia es para el que la mira y que su mirada es una invitación o evocación a los placeres secretos. También acá nos encontramos vivamente cuestionados por la obra, de lo cual puede resultar una incomodidad verdadera por encontrarse bajo la mirada sin equívoco.

Inversamente, el pintor nos presenta personajes que están dedicados a sus ocupaciones en un universo completamente ajeno al nuestro, y henos lanzados a una posición del que observa indiscretamente. Ciertamente, en la pintura clásica existen, al menos, reglas en las que el cuadro nos invita a una ceremonia a la que, aunque permanezcamos exteriores a lo que pasa, nos encontramos convidados. Las escena histórica, mitológica o simbólica tiene por función hacer públicos los personajes que ellas escenifican. No experimentamos, entonces, la desazón del mirón que sorprende con algún turbado placer una intimidad a la que no tiene derecho. Ocurre algo muy distinto si el pintor nos muestra hombres o mujeres, en sus secretas ocupaciones, como ignorantes de la mirada que les echamos. Una verdadera inquietud se instaura entonces en el espectador, actor a pesar de él, de una especie de indiscreción. Esa perturbación puede muy bien participar de la emoción estética, y los cuerpos sorprendidos del cuadro se vuelven los mediadores privilegiados de esa emoción. Muchos cuadros de Edward Hopper utilizan esta técnica pictórica que hace del espectador un voyeur. El efecto se acentúa cuando el personaje es captado a través de una ventana abierta o por el resquicio de una puerta medio entornada, sorprendido en una actitud o una actividad íntima, que parece ignorar nuestra mirada. De este modo, uno no puede dejar de pensar que la joven señora sentada, vista de espaldas, en Room in Brooklyn (Museum of Fine Arts, Boston) se levantaría y se daría vuelta hacia nosotros si sospechara nuestra presencia.

Asimismo, uno está llevado a creer que la del cuadro Morning in a city (Williams College Museum of Williamstown) se cubriría si nos descubriera observándola. La del Hotel Room (Museo Thyssen-Bornemisza de Madrid) así sorprendida en su pieza de hotel, sentada en la cama cerca de sus maletas no deshechas, no dejaría de levantar la cabeza de su libro si sintiera nuestra mirada. Y así se podrían multiplicar los ejemplos. 
Desde entonces, el hecho de que los observemos mientras se ignora nuestra presencia, o que nos miren y nos provoquen, el cuerpo representado introduce siempre la preocupación mediadora de la cual la emoción estética tiene necesidad.

De este modo, el arte hace del cuerpo la interfaz privilegiada de las emociones, las cóleras, los sentimientos más violentos, los más dulces y los más íntimos. $\mathrm{El}$ arte asegura, así, una comunicación interhumana al crear una complicidad entre el pintor, el escultor o el coreógrafo y sus espectadores. Lo mental, lo psíquico se reabsorben en la apariencia del cuerpo. Aquí reside su papel de interfaz.

\section{El cuerpo y el esfuerzo}

Sin embargo, los cuerpos que aprehendemos en una obra de arte son siempre cuerpos de otra índole y no estamos implicados físicamente en el proceso de comunicación. Ocurre algo muy diferente cuando se trata de poner en movimiento nuestro propio cuerpo en una actividad en la que él debe transmitir una significación. Esto se encuentra de manera ejemplar en el trabajo manual y en el ejercicio deportivo. Esto se debe a que el cuerpo nos pone en contacto con el mundo por medio del artificio y de la brutalidad. O más bien: si somos nuestro cuerpo, nos volvemos ese contacto. El bucle está rizado; por este tipo de actividad nos hacemos interfaz, interfaz radical; devenimos la pura comunicación material y nos reabsorbemos en ese proceso de comunicación y de apropiación. Nos realizamos como transmisores de formas y de sentido al ser la creación solamente una variante ambigua de la transmisión. Es ambigua porque la fuente no está claramente identificada y permite todas las ensoñaciones metafísicas y todas las hipótesis ontológicas, incluido el restablecimiento de la dualidad de lo interno y de lo externo. Contra de esta dualidad podemos tratar de pensar, en el trabajo manual y en la actividad deportiva, la interfaz replegada sobre ella misma.

El hombre comienza con la técnica y la herramienta. El prehistoriador da testimonio de ello, Leroi-Gourhan en particular. La relación del hombre con el mundo pasa por la herramienta en la que el cuerpo se prolonga, se imita y, a fin de cuentas, se catexiza. Por el cuerpo estamos en el mundo y, recíprocamente, el mundo está en nosotros. El hombre se constituye en su relación a la vez de sobrevivencia y de cultura a través de su cuerpo y, ante todo, su mano prensil. Somos, primero que todo, trabajadores manuales, incluso si la abstracción, la división del trabajo y la civilización han podido hacérnoslo olvidar. La historia occidental es un poco la historia de este olvido que ha podido llegar hasta el menosprecio. No regresaremos sobre esta historia que ha podido rodear la actividad material de misterio y de religiosidad esotérica (gremio o cofradía de oficiales artesanos), expulsarla de la esfera social aislándola en un medio 
deshumanizado (la revolución industrial), o bien escamotearla por el desarrollo de máquinas pantallas colocadas entre la actividad humana y la producción de bienes. Este último avatar de la empresa técnica, que precisamente estamos viviendo y que desprende cada vez más la transformación de las materias de una actividad manual, expulsa a esta del lado de un mito artesanal calcado sobre el espíritu de gremio o cofradía reconsiderado o revalorizado para enmascarar mejor - parece ser- el juego fundamental en el que el hombre toma la materia con sus dos manos. Jean-Claude Beaune (1998a) ha presentado magistrales análisis filosóficos de estas fluctuaciones del medio técnico. No volveremos sobre esto, sino que nos interesaremos más particularmente en el papel que juega el cuerpo en la actividad manual del trabajo.

Fundamentalmente, el menosprecio que agobia al trabajo manual hoy en muchos de los países industrializados, particularmente en Francia, y que hace de la enseñanza profesional la vía del fracaso, reposa sobre un perverso dualismo entre el cuerpo y el espíritu heredado de un cristianismo teñido de neoplatonismo. Si creemos que somos un cuerpo más un espíritu, que este último es la parte noble de nuestro ser y que a este título debe comandar al otro, entonces el trabajo manual debe ser guiado por el espíritu. División del trabajo: el espíritu comanda, el cuerpo obedece. Y se continuará esta división: para algunos es el espíritu y las tareas nobles, mientras que para otros es el cuerpo y sus frotamientos impuros con la materia. Esta división entre trabajo intelectual y trabajo manual —ya esbozada por el Platón de la Repúblicasolo tiene sentido con respecto a ese postulado dualista. Por ello, el cuerpo ha sido olvidado, minimizado y reducido a una posición subalterna y, por lo demás, no hemos terminado de deplorar sus consecuencias sociales. En el deporte, el cuerpo toma un estatuto que se le parece. Hablamos evidentemente del deporte tal como cada uno puede practicarlo, esto es, como libre ejercicio de sus facultades físicas en una actividad lúdica. Sin embargo, acá también subsiste un dualismo fantasmático del cuerpo y del espíritu. Es preciso mantener el cuerpo para que el espíritu, concebido como el contenido, se beneficie de la buena salud del continente, mens sana in corpore sano.

¿Se podrá invertir esta deriva dualista tanto en el dominio del trabajo como en el del deporte? Esto conduce a interrogarse sobre el rol del cuerpo en esas actividades y cómo, en tanto que interfaz, puede oscilar de la afirmación de sí a la desposesión de sí mismo.

Tomemos primero al trabajador manual, no todavía al obrero sino al artesano preindustrial, para quien el trabajo se rodea de toda un aura religiosa y mitológica tanto social como económicamente, y que el espíritu de cofradía sistematizó: el herrero, el carpintero, el tejedor... Nuestra noción de interfaz atrae manifiestamen- 
te nuestra atención sobre la herramienta. Esta está entre la mano y la materia prima, y es una interfaz tan evidente que nos enmascara finalmente la función corporal. Desde la Enciclopedia se ha expuesto y comentado la herramienta. ¿Pero qué queda si se la pone entre paréntesis? Queda un gesto, es decir, un movimiento disciplinado del cuerpo, una larga práctica que permite alcanzar la precisión inconsciente y segura. El movimiento por el cual se define el titular de un oficio no puede ser un movimiento calculado, reflexionado; debe tener algo de reflejo condicionado. Antes del instrumento o de su aparición, desde un punto de vista lógico y correlativamente en el tiempo, tiene que estar el cuerpo mismo plegado a una gestual ampliamente aprendida. El gesto debe plegarse a la forma en que se trata de obtener, y el cuerpo al gesto. La primera interfaz entre la finalidad productora de un bien y la materia prima es claramente el gesto, por ende, el cuerpo. Incluso, los gremios o cofradías jerarquizan a sus miembros, desde el aprendiz al maestro, en torno a esta maduración del cuerpo en movimiento. "No hay malas herramientas, solo malos obreros". El cuerpo es claramente la interfaz primera entre la materia y la serie indefinida de los objetos producidos. El trabajo artesanal articula así dos interfaces. Sin embargo, en cada instante una de las dos puede reabsorberse en la otra. Que la herramienta se reabsorba en la mano y estamos abordando las primeras obras; las del alfarero, por ejemplo. Lo inverso es posible puesto que el equilibrio puede romperse en los dos sentidos: el hombre se vuelve entonces una herramienta, un eslabón en una cadena de producción. La gran industria, el taylorismo aquí o el estajanovismo allá, son dos de los ejemplos. A veces se ha llamado reificación a este proceso que instaura la gran industria. En este último caso, el cuerpo sigue siendo claramente una interfaz, pero los términos que él conecta se le escapan en tanto que sujeto. Por un lado, solo se necesitará vender una fuerza de trabajo para sobrevivir; por el otro, sus gestos atomizados se encuentran desprendidos de una finalidad que sigue siendo oscura y deportada a una esfera que ya no es la del trabajo, sino la del provecho. Esta segunda reabsorción evidencia el carácter de interfaz que tiene el cuerpo, de manera a menudo trágica, por la pobreza, la miseria material y moral que la acompañan. Sin embargo, al mismo tiempo, la eficacia del cuerpo se vuelve medible y puede ser el objeto de una manipulación y de una constante mejora. El taylorismo conduce a la reducción progresiva del obrero al estatuto de autómata. Pero es también multiplicando las interfaces entre el cuerpo productor y el producto elaborado que la industria opera esta reducción. La máquina, mucho más separada del gesto primitivo de lo que lo estaba la herramienta, se constituye como una interfaz suplementaria. Ella va también en una complejidad creciente de las estructuras jerárquicas que organizan el trabajo: otras interfaces. Cada vez que una interfaz se añade entre el obrero y el producto, el primero queda un poco más despojado de su gesto largamente aprendido y su rol de interfaz corporal queda disminuido, simplificado y, a fin de cuentas, 
desvalorizado. Por ello, los ejércitos de obreros especializados pegados a las cadenas de montaje se confunden primero poco a poco con los órganos mismos de la gran máquina fabril. Por supuesto que quedarían por allí o por acá islotes donde se mantenían el gesto profesional y el saber cuasi artesanal. Esto es un poco como la traza siempre presente del fondo sobre el cual ha podido construirse la producción industrial. En efecto, debido a que nuestro cuerpo es esta doble interfaz inestable o metaestable, es posible la oscilación del artesanado a la fábrica moderna a través la etapa transitoria de la manufactura. Igualmente, sobre este fondo se podrá reemplazar al obrero por el robot, el autómata y la máquina. Cuando se haya separado suficientemente el gesto del obrero de su finalidad, ya medido, estudiado y superracionalizado, se lo transferirá a la máquina. La segunda interfaz, de la herramienta a la máquina-herramienta y luego al autómata, poco a poco toma el sitio de la interfaz corporal primitiva. Lo hemos dicho: si en el trabajo manual ponemos entre paréntesis la herramienta, solo queda el juego controlado de los músculos por el cual nos realizamos. Sin embargo, no hay acá un simple intermediario entre la voluntad de obtener un producto y ese objeto de nuestra necesidad o de nuestro deseo. En efecto, alejemos el mito de un trabajo redentor, incluso si la palabra estuvo en el origen ligada a la tortura. El hombre en el trabajo manual tiene mucho más que ganar que la remisión de sus faltas y alguna parte de paraíso. En el ejercicio muscular, que es todo trabajo en su origen, tomamos consciencia de nosotros mismos. La consciencia de sí no se explica probablemente por los movimientos del cuerpo, sino que estos son indispensables a aquella. En este sentido, concedemos que hay una dignidad del trabajo manual. Desde entonces, despojar al hombre de esta dimensión, como la sociedad industrial lo ha hecho, es atentar no solamente con su cuerpo considerado como simple autómata, sino también con su conciencia, puesto que nos negamos a separar lo uno de lo otro.

Se comprende también, en el marco de esta concepción del cuerpo interfaz, qué papel y qué significación pueden ser los del deporte. Platón fue el primero, y no se equivocó, que incluyó la gimnástica en la educación, en el encaminamiento hacia la filosofía y la sabiduría. El dualismo platónico aún le conservaba un rol al cuerpo en La República. Tenía una función en la ascensión que el espíritu debía emprender hacia el mundo de las Ideas. El éxito que tiene hoy la práctica del deporte en los países industrializados, y principalmente entre las personas que más alejados están del trabajo manual, no se explica simple y superficialmente por una necesidad biológica de actividad física, ni siquiera si esa necesidad existe. Se trata de mantener la función de interfaz del cuerpo, de la que la organización social del trabajo nos priva, incluso si está aún vacía, puesto que no hay, a fin de cuentas, nada por ganar. La transmisión de forma y de sentido, que debe asegurar una interfaz, se da vuelta entonces sobre sí misma. Nuestro cuerpo pertenece al mundo con el que se trata de entrar en comunicación, y 
esta comunicación de nosotros con el mundo se hace en nosotros, en nuestro propio cuerpo que quiere sentirse en su esfuerzo físico. El dualismo entre el espíritu y el cuerpo, entre la voluntad y el movimiento, se reabsorbe. En la actividad deportiva, la voluntad, el deseo y la percepción de sí no son más que este acto físico que se agota en sí mismo. La necesidad de actividad física y el deseo de "sentirse bien en su cuerpo" no son sino una manera de nombrar la función fundamental del cuerpo y los vestidos dualistas de una unidad que somos, consagrada a la inmersión en el mundo y a la comunicación permanente con el entorno. En una concepción dualista, las palabras no hacen más que proyectar sobre el individuo humano los dos polos de la interfaz; no debemos dejarnos agarrar por su apariencia. La expresión "estar bien en su pellejo" deja suponer que el cuerpo es, en el mejor de los casos, el lugar en el que habita el espíritu que uno debe convertir en confortable; y, en el peor de los casos, el cuerpo es un peso, una bola de hierro que es preciso aligerar en la medida de lo posible. Una concepción así puede fundar toda práctica y toda filosofía que busque desembarazarse de "al animal que hay en nosotros". Se carece entonces, ciertamente, de lo esencial de la humanidad, de su pesantez, su inmersión en un mundo que ella emprendió transformar desde que dio sus primeros pasos; se repliega un puro espíritu supuesto sobre su propia vacuidad. Entonces, toda la historia de la humanidad no debería aparecer más que como un fracaso indefinidamente recomenzado. Claramente, se podría explicar en este marco el menosprecio recurrente que se tiene del trabajo manual, pero no la necesidad igualmente constante que los hombres tienen de entregarse a una actividad física, necesidad tanto más marcada cuanto que ellos escapan al trabajo manual. Los ciudadanos griegos que estaban descargados de las tareas materiales por la esclavitud, iban al gimnasio o a la guerra. Asimismo, el señor feudal, al dejar al campesino y al artesano el cuidado de subvenir a sus necesidades, se entregaba a la cacería o a la guerra. Finalmente, el ejecutivo moderno, clavado a la silla y al escritorio, se vuelve un deportista de domingo, frecuenta los estadios o las salas de musculación.

\section{El cueppo instrumentalizado. El cuerpo representado, espejo del ser y del tener}

Si el cuerpo juega un papel de interfaz, se vuelve el lugar privilegiado de una comunicación interhumana, así como deviene un instrumento en procederes técnicos, económicos, políticos. El arte lo mantenía aún en la delgada línea entre el objeto y el sujeto. Todo un medio que la sociedad industrial occidental desarrolló le hace oscilar del lado del objeto, objeto de manipulación sin fin en las imaginerías más mercantiles o las más miserables. Cuerpo objeto, cuerpo instrumento, él se reabsorbe por entero en un papel de interfaz al haber perdido uno de sus polos. Y desaparece la oposición entre una exterioridad expresiva y una interioridad concebida como fuente de la significación. Todo 
se encuentra del lado de la pura exterioridad. La interfaz funciona al vacío. Se tratará claramente, aun con la publicidad o la pornografía, de apoyar un mensaje mercantil sobre la potencia expresiva del cuerpo y sobre los deseos profundos. Se pasa de lo uno a lo otro, pero por una escenografía que hace gestos o muecas, donde el sentido está remedado, automatizado y se da vuelta como en retroalimentación sobre su propia vacuidad. En la utilización que la publicidad hace de los cuerpos imita al arte, pero no lo alcanza, pues entre ella y el consumidor se intercala un objeto que a menudo no tiene nada que ver con el cuerpo; permanece inmanente al plan de mercado y comandado por la ley del provecho. El cuerpo que el arte exaltaba es rebajado al rango de una materialidad que sirve de intermediario entre otros objetos. El cuerpo es claramente aún una interfaz que no lleva a ninguna parte, sino que entra en una circularidad en la que todo sujeto no es sino un elemento de la pareja producción-consumo. El proceso de comunicación se encierra sobre sí mismo y se vuelve sordo y ciego. Desafortunadamente, ocurre lo mismo en el deporte espectáculo donde se proyectan sueños de pacotilla para que cada uno de nosotros olvide durante algunas horas la reificación en la que ha caído. Hemos visto el deporte como actividad o juego libre de los cuerpos. Pero este no es el deporte que asociamos a la publicidad.

La publicidad vuelve a poner en el proscenio la vieja dialéctica del ser y del tener o, más bien, absorbe de manera frecuentemente brutal el ser en el tener. Los personajes que se exhiben en los carteles y las páginas de las revistas y que se agitan en nuestras pantallas de televisión son claramente aún cuerpos, pero cuerpos que se volvieron soportes efímeros de un deseo, de unas ganas, rara vez de una verdadera necesidad, a fin de cuentas, de un producto que es necesario vender. Se dice que algunas civilizaciones conocieron la prostitución sagrada; los siglos pasados desarrollaron la prostitución crapulosa; el siglo XX añadió la prostitución blanda, suavecita. En este sentido, ya no sabemos muy bien lo que se está vendiendo, el perfume, el vestido, el carro o, más simplemente, un cuerpo humano dedicado a la contemplación de los más bajos deseos. El cuerpo se les escapa a los personajes de la publicidad, al maniquí y al atleta profesional de alto rendimiento para volverse el soporte de una mercancía, y también termina siendo una mercancía. Un maniquí asegura su belleza física como un particular asegura sus bienes. Tendrá una estrategia de hacer valer su cuerpo como un propietario terrateniente lo hace con sus tierras. También tendrá una misma estrategia para hacer valer en el deporte de alto nivel. La puerta está abierta a todos los extremos, a todos los errores, incluidos aquellos, torpes, que destruyen el bien que trataban de explotar, así como el que se ve en el dopaje. 
¿Cómo se ha llegado a una tal instrumentalización del cuerpo? La cuestión se impone más allá de la sana reacción moral que el filósofo puede experimentar. La existencia misma de un verdadero comercio del cuerpo no puede estar fundamentada más que en una característica esencial de él. Demasiado a menudo, la filosofía que ha querido olvidar el cuerpo en provecho de un puro espíritu, se ha vuelto incapaz de explicar semejantes desarreglos. Todo reposa sobre el hecho de que el cuerpo es visto y es visible, es reconocido y reconocible en tanto que tal. Por medio de su superficie, por su apariencia, lo descubrimos en el otro como si fuera vivido desde el interior de nosotros mismos. Una vez más hay un doble aspecto, o dos aspectos inseparables característicos de la interfaz: lo que une y separa al mismo tiempo. El cuerpo es a la vez sujeto y objeto, lo uno y lo otro. Militamos contra todas las tentativas esquizomorfas para mantener la integridad de esta interfaz. Las desviaciones mercantilistas que acabamos de señalar reposan, de hecho, sobre el abandono de uno de estos dos aspectos. Consisten en la basculación hacia el objeto o en un repliegue de la interfaz sobre una de las dos vertientes que ella conecta. Por supuesto, una tal mutilación de la realidad corporal tiene que ver con que el cuerpo puede ser tanto el nuestro como el del otro. $\mathrm{O}$, más bien, quiere decir que yo soy mi cuerpo y que yo miro el del otro como un objeto que surge en mi campo perceptivo. La interfaz solo se mantiene si reconozco en el cuerpo del otro algo de mi propio cuerpo. Sin embargo, el olvido es fácil, tanto más cuando la naturaleza de interfaz del cuerpo implica necesariamente su visibilidad, que él se ofrece como superficie. Si se distingue en demasía lo psíquico de lo somático, se divide al individuo en dos partes, y entonces será muy fácil olvidar una de ellas. El menosprecio del cuerpo que el espiritualismo ha exaltado permite rebajar al rango de mercancía la parte de materialidad humana a la que se limitaría el cuerpo.

El uso mercantil del cuerpo hace pareja con las filosofías "del cuerpo vivido", que lo repliegan sobre una interioridad desmaterializada y vacía, y niegan toda adherencia del hombre a la naturaleza ${ }^{12}$. Estas filosofías niegan a su vez una de las dos vertientes. El hecho de que se privilegie la exterioridad hasta hacer del cuerpo un objeto en medio de otros, susceptible de entrar en tanto tal en la economía de mercado, o que se exalte la interioridad como si ella pudiese ser captada por fuera de las trazas que ella deja sobre la superficie del cuerpo, se niega la totalidad que nos negamos a romper cuando defendemos el rol de interfaz que tiene el cuerpo. En este sentido, el concepto de interfaz es el único que puede permitirnos conservar la totalidad plenamente expresada en el movimiento permanente de lo interno hacia lo externo y recíprocamente. Lo psíquico y lo somático están estrechamente imbricados en las diversas

F. Tinland (1977) ha hecho una crítica minuciosa de esas filosofías en La différence anthropologique. Essai sur les raports de la nature et de l'artifice [ La Diferencia antropológica, ensayo sobre las relaciones de la naturaleza y del artificio]. 
manifestaciones que acabamos de ver y solo constituyen una única realidad. No podríamos separarlas sin un terrible empobrecimiento y sin hacer correr grave peligro a nuestra dignidad.

\section{El cueppo en pedazos: la cuestión de la "donación de órganos" y la de las manipulaciones genéticas}

Como acabamos de verlo, la concepción del cuerpo como interfaz no tiene que ver solamente con la ontología o con la metafísica, sino que posee implicaciones morales. Acabamos de ser llevados a fundamentar una condena del uso mercantil del cuerpo sobre algo bien distinto a un humanismo fofo o sobre una reacción puramente sentimental. Querríamos proseguir aún más este aspecto ético de la visión del cuerpo que acabamos de suscitar con la cuestión de los trasplantes de órganos y que los desarrollos de las técnicas médicas plantean de forma urgente. A esto responden las numerosas discusiones sobre los "comités de ética" y las tentativas de legislar de forma que se enmarquen las prácticas médicas.

Comencemos con la expresión consagrada actualmente para el uso de "donación de órganos", que no deja de plantear algunos problemas que querríamos examinar al comienzo, antes incluso de explicitar algunas de las recomendaciones que suscita la concepción del cuerpo interfaz. En efecto, discutiremos el término "donación". Si empleamos esta palabra, supone que existe una relación de propiedad entre yo y mi cuerpo, y que yo podría disponer de este como de un objeto que me pertenece. Uno no puede regalar sino lo que detenta a título de propiedad individual. Esto supone una exterioridad del cuerpo con respecto al yo o a alguna otra entidad no precisada, como el alma, que viviría de una manera independiente y que podría separarse de una parte de su bien. Esta noción de don introduce subrepticiamente la dualidad o el dualismo que acabamos de condenar en lo que precede. El cuerpo deja entonces de ser una interfaz; si el carácter gratuito del proceder del donante no hace que el cuerpo caiga en el uso mercantil, no por ello deja de colocarlo en una absoluta exterioridad. Ciertamente, siempre se puede analizar en términos de inconsciente o de proyecciones inconscientes la relación de propiedad, así como lo hizo, por ejemplo, Jung (1971):

Todo lo que me pertenece lleva como una impronta el hecho de ser mío, es decir una sutil identidad con mi yo. Algunas lenguas primitivas expresan este hecho de manera sugestiva cuando, por ejemplo, añaden el sufijo del ser viviente a la piragua si ella me pertenece, pero no si ella es de otro [...] Nuestros contenidos inconscientes están siempre en efecto proyectados mientras permanezcan inconscientes, y esta proyección se opera en todo lo que es mío. (pp. 305-306)

Por el momento concedamos esta perspectiva, pero no olvidemos que la identificación entre el yo y el objeto poseído tiene que ver con la proyección de un contenido del inconsciente que solo permanece en tanto sea inconsciente. 
Ahora bien, se trata claramente, en el proceder filosófico que preconizamos, el cual ha empujado siempre al hombre a conocerse mejor, de salir del inconsciente.

La segunda reserva que podríamos hacer sobre el uso de la expresión en cuestión tiene que ver con el hecho de que el don supone siempre un retorno, un intercambio, una reciprocidad. Es evidente que un legado de sus órganos, luego de su muerte (al menos de la cerebral), no puede prestarse a ningún tipo de reciprocidad o a ningún intercambio. Esta gratuidad, esta generosidad, serían verdaderamente admirables. Evidentemente, no queremos discutir el carácter altamente moral de la actitud del que prevé autorizar la extracción de órgano de su cadáver; lo que discutimos es que esto puede tener que ver con el don, que supone una relación de exterioridad, de propiedad y de intercambio que no nos parece que convenga al cuerpo tal y como lo hemos concebido hasta acá.

Si nuestro cuerpo es la interfaz que hemos descrito y nosotros somos nuestro cuerpo, entonces este no es un bien del que podamos disponer, como tampoco otros lo pueden hacer a nuestro nombre. De este modo, esto excluye la idea de que se pueda considerar una "venta" de órganos y cualquier pago por la extracción que se haga cuando la persona aún está viva, como en el caso de una "donación de médula ósea" o de un "regalo de un riñón", así se haga post mortem. Esto excluye también la idea de que la familia pueda decidir en lugar a nombre del difunto, como si ella heredara su cuerpo al mismo título que otros bienes. A este respecto, la legislación francesa actual obliga que los médicos pregunten a los parientes del difunto sobre la extracción de órganos de su cadáver y su testimonio sobre la real intención del muerto. Al tener que hacer este procedimiento con urgencia, nos imaginamos la dificultad de la familia solicitada para que rinda un testimonio en el clímax de su duelo. Esto dificulta mucho más la tarea de los médicos que se ven obligados, así, a añadir un terrible problema de conciencia a un dolor. ¿Cómo puede la familia, en efecto, interpretar objetivamente en ese momento de crisis lo que habría sido la voluntad del muerto? Su manifestación no puede ser más que la impronta de la subjetividad adolorida de sus miembros, y por esto escapa a una clara y objetiva apreciación de lo que hubiera deseado el difunto. Añadamos que, en Francia, a la hora en que escribimos estas líneas (2001), existe un fichero de negativa en el que cada uno de nosotros puede hacerse inscribir si desea firmemente que ningún órgano le sea extraído de su cuerpo privado de vida. En virtud del principio de que la ausencia de negativa explícita equivale a una aceptación, el médico es libre de disponer del cadáver bajo reserva del protocolo que hemos indicado acá. Como se ve, el marco jurídico es por el momento complejo y ambiguo, por no decir alambicado. Por ello mismo, puede prestarse a inevitables contestaciones, entrabar considerablemente el desarrollo de los trasplantes de órganos, y mantener una penuria constante que se traduce cada año en numerosos decesos que hubieran podido evitarse. 
Esta ambigüedad reposa en el hecho de que no se ha respondido claramente a la pregunta: ¿qué es un cadáver? ¿El cuerpo privado de vida es aún alguien? En la medida en que estamos todavía vivos, nosotros solo somos nuestro cuerpo y nos confundimos con él, a pesar de los esfuerzos de abstracción del dualismo filosófico; este cuerpo, tanto el nuestro como el de los otros, toma un carácter sagrado. Este carácter se pierde irremediablemente desde que la vida cesa. Sin embargo, tenemos muchas dificultades en aceptar que lo que hasta este momento era una persona oscila súbitamente en el orden de las cosas. El cuerpo privado de vida deja de ser la interfaz que hemos descrito y cae en la pura exterioridad. Tratamos entonces de mantenerlo artificialmente en este orden perdido, por el sesgo de la relación de propiedad, como si al concederle esta cualidad, eventualmente transmisible por herencia, permaneciera en la esfera de lo humano; de ahí el semblante de recurso a los que tienen derechos.

Esta tentativa desesperada de engañar la muerte, si queremos reflexionar un poco sobre ella, adquiere un carácter irrisorio. Se requeriría algo más que una simple relación de pertenencia y de propiedad legalmente reconocida para mantener el cuerpo en el dominio de la interfaz. Esto es así tanto más cuanto que esta relación, como acabamos de verlo, niega fundamentalmente el carácter de interfaz del cuerpo, muerto o vivo, y lo proyecta al dominio de la pura objetividad. Acabamos de mencionar a Jung y al inconsciente. Asimismo, hemos señalado hasta qué punto la propiedad, al menos cuando es aplicada al cuerpo, tenía que ver con una proyección de contenidos inconscientes. Pero el inconsciente soporta contradicciones que ya no podemos aceptar a nivel de una clara conciencia. No se salvará al cadáver del estatuto de cosa haciendo de él el contenido de una relación de pertenencia u objeto de transacción. Solo se lo puede salvar volviéndolo a colocar en un juego de relaciones donde él conserve - así sólo sea en el espacio de un instante más allá de la muerte- su función de interfaz. Ahora bien, el único espacio en el que se puede llevar a cabo un mantenimiento así es evidentemente la comunidad humana en la que vivió el individuo. Esto implica evidentemente que el muerto sea rodeado de los ritos sociales del duelo que la comunidad testimonie de una manera o de otra, bien sea por medio de una ceremonia o por una plaza reservada en su territorio (el cementerio). En este marco, la extracción de órganos es un medio particularmente fuerte para reintegrar el cuerpo abandonado por la vida al orden humano de la interfaz. Sin embargo, esto supone que la cuestión de la extracción de órganos no tiene que ver solamente con una deliberación individual que cada quien puede tomar en vida, y mucho menos con una apreciación de los parientes en un momento en que son menos aptos para formularla, sino con una regla de la comunidad. Se podría entonces aceptar el fichero del rechazo como algo que tiene que ver con la deliberación consciente y con la voluntad claramente expresada de una persona, pero sería necesario retirar la hipócrita petición de testimonio por parte de los 
familiares sobre las intenciones del muerto cuando él no se hizo inscribir en el fichero. Se preservan así las prerrogativas de la persona. Inversamente, no estaríamos de acuerdo con un fichero que consignara la voluntad de los vivos de "hacer donación" de sus órganos luego de su muerte, porque en tal caso las prerrogativas de la sociedad serían lesionadas. Esta es, a fin de cuentas, la posición clara que podemos fundar sobre la concepción del cuerpo que hemos defendido hasta aquí. Cualquiera que no haya rechazado claramente que sus órganos sean extraídos de su cadáver, por un procedimiento voluntario de inscripción en un fichero, podría sufrir post mortem tales extracciones sin que sea necesario pedirle autorización a nadie. Un cuerpo que ha dejado de vivir no pertenece a nadie, y solo una integración en el conjunto de las relaciones comunitarias puede permitirle conservar por algunos instantes su estatuto de interfaz, es decir, no ser ni una pura interioridad (lo que es de aquí en adelante imposible) ni una absoluta exterioridad; la extracción de órganos con miras a un trasplante tiene que ver con esta integración. Aquel del que alguna parte del cuerpo continúa viviendo en otro cuerpo asegura aún la función fundamental de intermediario de la vida consciente.

Seguramente que se nos va a reprochar aquí enunciar una regla general, ciertamente fundada en la investigación que precede, pero difícil de aplicar a una multitud de casos concretos. ¿Qué hacer con la extracción de un riñón o de la médula de una persona viviente con miras a salvar otra o, más simplemente, con la donación de sangre? Evidentemente, estas preguntas no plantean problemas morales en la medida en que el "donador" es necesariamente voluntario. Sin embargo, ¿no estamos en estos casos en presencia de verdaderas donaciones que harían del cuerpo del donante un objeto que él podría ceder? El motivo es noble, ¿pero no rebaja el proceso al cuerpo al estatuto de objeto? En primer lugar, notemos la inteligencia de la legislación francesa que impone la gratuidad absoluta de tales actos y, cuando es posible, el anonimato del donador para el que lo recibe; es el caso en lo que concierne a la sangre. Estas dos medidas, que suprimen toda idea de intercambio o de reciprocidad, bloquean el ut do des (dono para que tu dones) y orientan el proceso hacia otras motivaciones. Desafortunadamente, no pasa lo mismo en la mayor parte de los países. En algunos casos, la pobreza ha podido conducir a un verdadero y odioso tráfico de órganos. Tales prácticas aparecen entonces como perversiones de un proceder que se puede pensar de otra manera. En efecto, estos dones efectuados por personas vivientes no equivalen al abandono de una propiedad en beneficio de un tercero, sino a una función del cuerpo como conexión particularmente fuerte para cimentar la comunidad humana. En particular, el anonimato reemplaza la relación de una persona con otra por la relación de un individuo con la comunidad a la que pertenece. Por esto mismo, esta relación, a menudo abstracta, toma una forma concreta y el cuerpo goza plenamente, una vez más, un rol de interfaz. 
Un segundo problema es la extracción de órgano del cuerpo sin vida de un niño, un joven o cualquier persona que, al no tener la mayoría de edad, no puede, en principio, inscribirse voluntaria y libremente en el registro de la negativa. Actualmente, toda extracción sobre un menor solo se puede efectuar con la autorización de los padres. ¿Habrá que mantener esta regla? ¿No instaura ella un derecho casi de propiedad de los padres sobre sus hijos? Sin embargo, si so pretexto de hacer prevalecer el vínculo comunitario sobre el lazo familiar se retirare esta regla, ¿no se rompe un vínculo por otro, y el segundo, sobre el que reposa la comunidad, no es el fundamento del primero o, por lo menos, no es su forma elemental? La cuestión es saber cuál es la naturaleza, o cuál debería ser la naturaleza de la relación de padres e hijos desde el punto de vista del cuerpo de los unos y de los otros. ¿Será que si rehusamos la herencia del cuerpo de los padres a sus hijos -lo que supone la autorización de la familia para extraer los órganos de un padre fallecido- simplemente tendremos que hacer simétrica o recíproca esta regla suprimiendo la autorización de los padres para una extracción en un hijo? Lo hemos dicho; la respuesta a esta pregunta supone una aclaración filosófica de los lazos familiares. Si los padres no tienen o no pueden tener un derecho de propiedad sobre sus hijos, ellos asumen, sin embargo, las responsabilidades que estos no pueden tomar. Es entonces a este título que ellos pueden intervenir en un procedimiento de extracción de órganos post mortem. Esto nos llevaría manifiestamente demasiado lejos de nuestro propósito, y dejaremos una tal respuesta en suspenso. Simplemente, seguimos persuadidos de que un tal examen deberá tener en cuenta el cuerpo concebido como interfaz. No habrá que considerar el cuerpo del niño como un objeto, propiedad de los padres (lo que haría de él una pura exterioridad), sino como una totalidad humana de lo interno y de lo externo en vías de constituirse. El examen de este proceso de constitución podrá aclarar la búsqueda de una respuesta auténticamente moral a esta cuestión.

De la misma manera, la concepción del cuerpo que acabamos de desarrollar puede aclarar las cuestiones planteadas por los más recientes descubrimientos de la genética. ¿En qué medida tenemos derecho a intervenir en el genoma humano? ¿En qué límites? ¿Por cuáles razones? Si el genoma es un abreviado del cuerpo, todo lo que hemos dicho del cuerpo en general vale para él, y en particular no podemos sino condenar el uso mercantil que de él pudiera hacerse. En este sentido, las secuencias descubiertas en el trabajo de desencriptado no pueden ser objeto de patentes en ningún caso. Si se deja al programa genoma humano confundirse con apuestas industriales y económicas, se empuja al cuerpo del lado de la cosa y de la mercancía y este es privado de su función de interfaz. Igualmente, no podemos sino emitir nuestras más vehementes reservas con respecto a la acción de Craig Venter y a la empresa Celera, así como con la lógica industrial con que opera. Lo que hace el debate en torno a esta cuestión 
particularmente perturbado es que la investigación en este dominio puede estar motivada oficialmente por el tratamiento a término de las enfermedades genéticas. ¿Se deberá rechazar un enfoque del cuerpo que puede llegar a aliviar sufrimientos? Ciertamente no. Sin embargo, se sabe que los mismos descubrimientos pueden desembocar en una verdadera selección artificial aplicada al hombre. Se puede impedir el nacimiento de algunos individuos juzgados a priori como no deseables, y luego se favorece la de individuos juzgados como más dotados. Incluso si dejamos de lado las apuestas financieras que animan las investigaciones en este sentido, tenemos aquí planteada la cuestión de un eugenismo por fin eficaz.

En el marco de nuestra reflexión, la cuestión es saber si un tal eugenismo es compatible con la función interfacial del cuerpo. De la misma manera que concebimos que una terapia fundada sobre el conocimiento adquirido de la codificación genética acrecienta la función de interfaz del cuerpo en la medida en que ella lo libera de las limitantes que lo mantienen en el orden de las cosas y de la pura exterioridad, también nos parece que el eugenismo falsea esta función. ¿Por qué? El individuo que nazca de una selección ya no sería el resultado de un encuentro que posee la parte de azar que la vida conlleva siempre consigo y que se mezcla con la necesidad de los mecanismo de herencia ${ }^{13}$. Un tal individuo ya no es sino una construcción fundada en juicios de valor. Sin embargo, esos juicios que deciden sobre lo que es bueno o malo, aceptable o no, robusto o no, exigirían ser fundamentado a su vez. Ahora bien, en este punto estamos remitidos a marcos éticos de los que sería fácil mostrar que sus caracteres están frecuentemente ligados a una época, a una cultura, a una civilización. Las sociedades puritanas que hemos conocido en Europa occidental probablemente habrían juzgado benéfico no dejar venir al mundo un individuo homosexual, si es que se pueda imaginar la existencia de un gen de la homosexualidad, lo que está lejos de ser probado. Por el contrario, Grecia o Roma no habría visto en ello ningún inconveniente en ciertas épocas antiguas,. De una práctica así nacerían cuerpos fijados por proyectos que los rebasarían. Tendríamos individuos tan perfectamente determinados por una voluntad que los habría precedido, que no les quedaría más que cumplir con su destino.

Se ve claramente que hay en el proyecto eugenista una negación radical de nuestra existencia en un cuerpo en correlación con el mundo, un cuerpo que pertenece al mundo y que de él se desprende, que ha sufrido su ley y siempre transgrede sus decretos para apropiársela mejor. Pero vayamos más lejos. La concepción de un cuerpo interfaz supone algo que la ciencia comienza a revelarnos: que nunca hemos sido los puros herederos de nuestros genes. Heredamos igualmente nuestro entorno, nuestra cultura, nuestra comunidad.

13 Cfr. la célebre obra de Jacques Monod (1971), El Azar y la Necesidad. 
El propio mecanismo de la herencia genética no es para nada simple en el sentido de que a cada carácter de nuestra individualidad le correspondería un gen identificable. No hay relación biyectiva entre las secuencias del genoma y el conjunto de nuestros atributos. El carácter reticular de la interfaz se encuentra en la constitución y el funcionamiento de la combinatoria genética. Ahora bien, el funcionamiento de una red compleja, y eventualmente su control, no puede hacerse simple y mecánicamente. La experiencia — por ejemplo, en informática con las redes de neuronas formales - muestra que una tarea así requiere una parte de azar, así sea controlado. En el caso de las redes de neuronas formales que acabamos de evocar, se utilizará por ejemplo las cadenas de Markov (es decir, los grafos cuyas aristas son ponderadas por probabilidades). Decir esto no es decir que técnicamente el eugenismo sea imposible, sino solamente otras dos cosas: la primera que su puesta en funcionamiento no puede ser simple y perfecta; la segunda, que comprometerse en una tal perspectiva es negar a priori el carácter de interfaz que le hemos concedido a nuestro cuerpo como el modo de existencia humana. Si un día nuestros conocimientos del genoma nos permiten prácticas eugénicas eficaces y generalizadas y, por tanto, una evolución controlada de la especie, habremos salido del orden humano. No podemos decir entonces en qué orden habremos entrado, pero será preciso fundamentar los juicios de valor a partir de los cuales orientaremos deliberadamente la evolución, y esto parece bien difícil en la actualidad, a menos que nos hundamos en alguna irracional creencia en gurús. El precio a pagar sería entonces abandonar la razón, esto es, aquella misma a la que le deberíamos nuestro poder. He acá cómo solo se puede llegar a una inverosímil contradicción. Fabricar superhombres o erradicar el pecado original por fin descubierto en la organización genética, y así volver al paraíso perdido, tiene que ver con el más peligroso de los delirios.

\section{Una aproximación filosófica del cuerpo interfaz: la obra de François Dagognet}

¿Se puede incluir, más allá de estas pocas descripciones que hemos dado del cuerpo que funciona como una interfaz y de las pocas prescripciones éticas que de ello se deriva, la noción de cuerpo interfaz en una visión filosófica más amplia? Somos bien conscientes que por el momento solo hemos explorado diversas manifestaciones del cuerpo: la expresión de las ideas, los estados mentales, las creencias en sus formas y sus adornos, su uso en el arte como medio de la emoción estética, su parte en el trabajo y de una manera general en el despliegue físico de toda realidad humana. ¿Podemos ir más lejos? ¿Se puede encontrar a algún filósofo que le dé un estatuto eminentemente filosófico al cuerpo considerado como interfaz?

En este estadio de nuestra reflexión, muy naturalmente, nos daremos vuelta hacia la obra de François Dagognet. Médico, psiquiatra y filósofo, es capaz, más 
que ningún otro, de aclararnos sobre la naturaleza del cuerpo al que aprendió a leer o a hacer hablar.

Ante todo, por el método que ha puesto en funcionamiento, François Dagognet fue conducido a interesarse en las interfaces. De entrada, él rechaza las visiones simplistas, las dicotomías fáciles, las primeras apariencias y, en este sentido, es claramente el heredero de Gastón Bachelard. Para él la realidad es compleja y provoca una recolección minuciosa de los signos y de las trazas. Tras el científico, siguiendo al biólogo y al médico, el filósofo deberá mostrarse atento a los instrumentos y a los montajes de todo tipo que puedan revelar lo oculto o lo subterráneo. Al anteojo que procura un alejamiento artificial sobre las cosas y las ahoga en una totalidad a veces coloreada, pero con frecuencia indiferenciada, François Dagognet (1982) prefiere el microscopio que aísla el detalle, descompone y transpone, por lo que "se necesitan montajes, descomposiciones y una instrumentación. Nada se ve al ojo desnudo, o muy poco". Por esto mismo, el elogio permanente que hará de Étienne-Jules Marey y de su arte de inscribir los movimientos más finos, de poner de relieve los signos y las trazas más fugaces (Dagognet, 1987). Precisamos aprender a leer en la superficie, los dramas internos o disimulados. Es menester colocarse deliberadamente allí donde los términos opuestos se codean o se invierten el uno en el otro, es decir, en la interfaz. Este método es constante en la obra de François Dagognet (1964, 1993) desde La Razón y los remedios hasta La Piel descubierta ${ }^{14}$, respectivamente. Lo pondrá en funcionamiento en numerosos dominios que van desde la medicina hasta la ecología, pasando por la geografía, la química (Dagognet, 1969) ${ }^{15}$ o el arte, mostrando siempre su pertinencia. El detalle, al que los resúmenes totalizadores o demasiado amplios descuidan, es vuelto a colocar en el centro de la reflexión y se vuelve allí revelador. El todo no puede ser captado más que a través de las partes que lo manifiestan. Toda filosofía comienza por una averiguación casi policíaca, y François Dagognet la prosigue incansablemente en su obra. Ella misma se vuelve la interfaz inevitable entre lo real y su representación racional y científica. A este respecto, Cuadros y lenguajes de la química es un logro de método particularmente significativo.

La imagen, y la del cuerpo humano en particular, se encuentra aquí rehabilitada. No se trata de la imagen inmediata ni de la percepción primera -el epistemólogo François Dagognet no ha olvidado las lecciones de su maestro Gastón Bachelard—, sino la imagen elaborada, trabajada, desajustada. El

14 En sus idiomas originales: La raison et les remèdes: essai sur l'imaginaire et le réel dans la thérapeutique contemporaine, y La peau découverte.

15 En esta obra, titulada originalmente Tableaux et langages de la chimie [Cuadros y lenguajes de la química], el filósofo, al instruirse en la historia de la química, evidencia las interfaces representacionales a través de las cuales organizamos el mundo material. 
médico sabe qué papel juega la imagenología médica en el conocimiento que se puede alcanzar del cuerpo que sufre. Sin embargo, la imagen médica nunca es una imagen desnuda; resulta de un trabajo de desplazamiento, elaboración y de construcción a través de una instrumentación robusta y compleja. Son los mismos procedimientos que el geógrafo emplea para leer el paisaje a través de las imágenes satelitales que fueron tomadas en el dominio del infrarrojo y reproducidas en "falsos colores". En este sentido, François Dagognet tiene razón cuando ve en los trabajos de Marey una renovación revolucionaria del enfoque científico de la fisiología, e incluso lo que va a transformar profundamente nuestro mundo al darle a la imagen el sitio inmenso que en la actualidad ocupa. Este interés por la imagen, trabajada en la que lo real se manifiesta, conducirá al médico y al filósofo a una atención minuciosa por los procedimientos del arte y particularmente del arte moderno.

Esta rehabilitación de la imagen, y esa preocupación constante por la superficie y por la interfaz, van a la par con una desconfianza profunda por las filosofías de las profundidades. Se ha acusado a veces a François Dagognet de defender un positivismo obsoleto y de ser más discípulo de Augusto Comte que de Gastón Bachelard. A nuestra manera de ver, se equivocan en esta crítica y lo hacen doblemente. Primero, no hay pecado en reconocer en la obra de Auguste Comte preciosas lecciones. Este filósofo a menudo ha sido injustamente desacreditado. Segundo, lo que se toma por positivismo en Dagognet es claramente, más bien, el rechazo de cierto discurso filosófico que se vuelve incansablemente sobre sí mismo, en logorreas estériles, y que confunde la profundidad con el vacío. Se puede jugar sin cesar con las oposiciones que sugiere el lenguaje, entre superficial y profundo, entre interno y externo, entre en-sí y para-sí, entre ser y nada, entre actos de conciencia y objetos de la consciencia (cogito y cogitata), entre psíquico y somático. De esta manera, se olvida preguntarse qué realidad permanece bajo esas oposiciones e, incluso, si ellas reflejan una realidad distinta a la puramente verbal. François Dagognet comprendió que el juego es estéril y rompió deliberadamente con esos dualismos. De entrada, se coloca donde los términos opuestos se reencuentran, es decir, en las superficies, en las fronteras y en los límites. La piel, en el caso del cuerpo, se vuelve entonces el lugar privilegiado del conocimiento antropológico (Dagognet, 1993). Es el lugar donde lo interno se exterioriza y donde se interioriza lo externo. "La piel define indiscutiblemente la interfaz entre el adentro y el afuera, dos mundos por lo demás inseparables; ¿qué se volvería el interior si ignorase el exterior que lo rodea?" (Dagognet, 1993, p. 8). Las filosofías de la profundidad han privilegiado lo interno, el psiquismo, lo mental, y han ignorado lo externo y lo somático. Ahora bien, François Dagognet (1993) rechaza esta separación; pues lo uno no va sin lo otro. "A la inversa, nosotros no dejaremos de valorizar la alianza del 
adentro y del afuera, su encuentro, su inseparabilidad; y ellos están a tal punto juntos que podremos alcanzar el uno a través del otro" (p. 18).

Por ejemplo, el tradicional dualismo entre materia y pensamiento se encuentra superado en un proceder de "rematerialización" (Dagognet, 1989b) ${ }^{16}$. Se tratará de penetrar en

esa región medianera, tan vituperada -por no decir, de ahora en adelante, prohibida- donde lo espiritual (la psiquis) y lo somático se desposan tan bien que ya no pueden divorciarse, donde lo mental se corporeiza, de la misma manera que el cuerpo individual expone enigmáticamente, pero por entero, las energías del yo. (Dagognet, 1982, p. 3)

Digamos una vez más que se necesita que nos coloquemos en la interfaz que entremezcla y confunde los opuestos al mismo tiempo que los individualiza. No hay conciencia pura ni pura materialidad, sino un mixto que se revela en las fronteras que lo recorren. Entonces, habla al mismo tiempo el psiquiatra y el filósofo, el que conoce las controversias entre psicoterapia y quimioterapia, el que nunca ha dejado de reconocer, contra las filosofías del sujeto (transcendental o no), las virtudes de la segunda. Frente a los idealismos contemporáneos, François Dagognet retoma un camino que no deja de evocar el de Aristóteles ${ }^{17}$ frente al dualismo platónico. Este último, cuando hace del alma la forma del cuerpo, liga indisolublemente la una al otro. Sobre la base de este monismo, François Dagognet no cesa de reclamar que se puede desarrollar una concepción del cuerpo interfaz que justifique los análisis que acabamos de realizar.

Si el cuerpo es la interfaz entre lo interno y lo externo, entre el adentro y el afuera, entre lo psíquico y lo somático, no lo sería tanto debido a que el uno expresaría al otro como a un reflejo. Precisamos llegar más lejos aún y llevar hasta el fondo las consecuencias de lo que nos entrega la práctica de la traceología y de la semiología: "El afuera traduce claramente el adentro no porque lo refleje sino porque lo invierte" (Dagognet, 1982, p. 45). El cuerpo no es sino un alma a la que se le ha dado vuelta, y por ahí ha salido a la luz. Así, en la superficie que se da a ver, se puede desarrollar una lectura minuciosa, una exégesis (Dagognet, 1982, p. 47) que abre a la totalidad individual. No se repelerá la conciencia a las profundidades insondables; el cuerpo la lleva a plena luz a través de las huellas y de los índices. "Finalmente, ¿qué es un cuerpo animado sino un

16 Este libro fue traducido por Luis Alfonso Paláu-Castaño (2007) con el título Rematerializar. Materias y materialismos. trad. Luis Alfonso Paláu para el curso "Materiólogos y objetología" de la Escuela de Estudios Filosóficos y Culturales de la Facultad de Ciencias Humanas y Económicas de la Universidad Nacional de Colombia en el año 1999.

17 Por lo demás él hace explícita referencia a Aristóteles y a su concepción del alma como forma del cuerpo, en un artículo aparecido en la revista Poïesis, Les leçons du corps vivant [Las Lecciones del cuerpo viviente] (Dagognet, 1998a). Evidentemente, también se podría evocar a Spinoza, para quien el alma es la Idea del cuerpo. Y François Dagognet, en ese artículo, no hesita en asimilar la forma y la idea. 
cementerio de signos y de trofeos?" (Dagognet, 1982, p. 47). Inversamente, por este hecho tenemos siempre la psiquis de nuestro cuerpo. Más allá de los abusos y de las derivas que conocemos, François Dagognet no dudará en volver a situar los trabajos de Lavater en una historia de los progresos de la antropología.

El cuerpo es una interfaz, y toda su riqueza reside en el hecho de que es a la vez una frontera y un límite, pero también un lugar de intercambios. "Separa y al mismo tiempo mezcla los dos universos que se encuentran en ella, que comunican una parte de su tintura generalmente a ella. Se convierte en una fructífera convergencia" (Dagognet, 1982, p. 30). Pensar el cuerpo como interfaz es de cierta manera, en Dagognet, rechazar los dualismos recurrentes en filosofía y rehusar concebir el pensamiento separado del cuerpo. De acá nacerán dos elementos importantísimos de la filosofía de François Dagognet. En primer lugar, él desarrolla los fundamentos de una biopsiquiatría (Dagognet, 1982). El enfoque psicoanalítico de los malestares y de los dramas se encuentra reorientado:

el animal, y el niño, en el curso de su existencia, deben atravesar dramas; en lugar de orientar esto sobre una hipotética sexualidad infantil (la escuela freudiana), es posible dar cuenta de esto a través de un punto de vista sensorialista.(Dagognet, 1993, p. 72)

En este sentido, el cuerpo reencuentra un lugar central en la estructura psíquica. En segundo lugar, de ello resulta un enfoque nuevo de la moral, en filigrana en numerosas obras, pero que recientemente encontró su expresión abierta en Por una nueva moral (Dagognet, 1998b) ${ }^{18}$.

\section{Conclusión}

Se comprende desde entonces que los análisis que hemos intentado hasta aquí encuentran en la obra de François Dagognet alguna justificación filosófica. Toda pesquisa sobre la noción de interfaz debe necesariamente hacer un desvío por esta obra. Ciertamente, nuestra travesía no es más que una breve ojeada sobre una materia mucho más rica que lo que algunas páginas pueden decir de ella. No se trata tampoco de apuntalar nuestras debilidades con el recurso fácil al magister dixit. Sin embargo, la honestidad quiere que uno reconozca sus deudas. Nos habría sido muy difícil evocar el cuerpo interfaz, como acabamos de hacerlo, sin referirnos a los trabajos de François Dagognet.

18 El título en el idioma original es Une nouvelle morale: travail, famille, nation.Este texto fue traducido por Luis Alfondo Paláu-Castaño (2006- 2009). Luego vinieron Comment se sauver de la servitude? Justice, école, religión [¿Cómo salvarse de la servidumbre? Justicia, escuela, religión] (Dagognet, 2000); Changement de perspective : le dedans et le dehors [Cambio de perspectiva, el adentro y el afuera] (2002a); Questions interdites [Cuestiones prohibidas] (2002b). Estos textos fueron traducidos por Luis Alfonso Paláu-Castaño (2006, 2009a, 2009b). 
De esta manera, el hombre va al hombre por la intermediación de su cuerpo. A través del descubrimiento de nuestro cuerpo y los usos que podemos hacer de él, alcanzamos esta especificidad reflexiva de lo humano. El etólogo ya lo subrayaba. Konrad Lorenz (1985) escribe:

El descubrimiento del propio cuerpo y, sobre todo, de la propia mano como cosas explorables entre otras, no necesita representar una reflexión genuina. Aún no ha despertado ese asombro ante el propio yo que se suele caracterizar como el inicio primigenio del filosofar. Pero, por lo pronto, la simple penetración cognoscitiva en el hecho comprobable de que el propio cuerpo o la propia mano es una "cosa" más del mundo externo y tiene propiedades constantes, características, a semejanza de cualquier otro objeto en el medio ambiente, debe haber tenido una significación muy honda y realmente sensacional en el sentido más puro de la palabra, en la vida animal. (p. 228)

Por lo demás, se ve aquí que la reflexión propia del hombre está estrechamente ligada a la evolución del cuerpo que autoriza una tal percepción de sí mismo, es decir, la estación erguida, la visión de frente y la liberación de la mano para la prensión. Además, tenemos que nuestro cuerpo o nosotros mismos, si nos negamos a separar el espíritu de su sustrato material, se encuentra hundido en un universo de cosas y de hechos donde las interfaces de toda naturaleza se multiplican, bien sea que se trate de objetos dados que utilizamos como otros tantos intermediarios o que se trate de objetos fabricados con miras a una tal finalidad. Requerimos pues proseguir nuestra averiguación.

\section{Referencias}

Beaune, J. (1998). Philosophie des milieux techniques. La matière, l'instrument, l'automate. Champ Vallon.

Chazal, G. (2000). Les réseaux du sens: de l'informatique aux neurosciences. Champ Vallon.

Chazal, G. (2002). Interfaces: Enquête sur les mondes intermédiaires. Champ Vallon.

Chazal, G. (1997). Formas, figura, realidad. Traducido por Luis Alfonso Paláu C., Medellín, 2011.

Dagognet, F. (1964). La raison et les remèdes: essai sur l'imaginaire et le réel dans la thérapeutique contemporaine. PUF.

Dagognet, F. (1969). Tableaux et langages de la chimie. Seuil.

Dagognet, F. (1982). Faces, Surfaces, Interfaces. Vrin. Caras, superficies, interfaces. Traducido por Luis Alfonso Paláu C., Medellín, 2007a.

Dagognet, F. (1986). Philosophie de l'image. Vrin. Filosofía de la imagen. Traducido por Luis Alfonso Paláu C., Medellín, 2007b.

Dagognet, F. (1987). Étienne-Jules Marey. Hazan.

Dagognet, F. (1989a). Corps réfléchis. Odile Jacob.

Dagognet, F. (1989b). Rematérialiser: matières et matérialismes. Vrin. Rematerializar: materias y materialismos. Traducido por Luis Alfonso Paláu C., Medellín, 1999. 
Dagognet, F. (1992). Le corps multiple et un. Laboratoires Delagrange. El Cuerpo múltiple y uno. Traducido por Luis Alfonso Paláu C., Medellín, 2007c.

Dagognet, F. (1993). La peau découverte. Synthélabo. La Piel descubierta. Traducido por Luis Alfonso Paláu C., Medellín, 2009.

Dagognet, F. (1998a). Les leçons du corps vivant. Poïesis, Architecture, Arts, Sciences et Philosophie, (8), 105-136.

Dagognet, F. (1998b). Une nouvelle morale: travail, famille, nation. Synthélabo. Una nueva moral: trabajo, familia, nación. Traducido por Luis Alfonso Paláu C., Medellín, 2009b.

Dagognet, F. (2002a). Changement de perspective: le dedans et le dehors. Table Ronde. Cambio de perspectiva: el adentro y el afuera. Traducido por Luis Alfonso Paláu C., Medellín, 2006.

Dagognet, F. (2002b). Questions interdites. Synthélabo. Cuestiones prohibidas. Traducido por Luis Alfonso Paláu C., Medellín, 2009c.

Galton, F. (1892). Fingerprint.

Granger, G. (1999). La Pensée de l'espace. Odile Jacob.

Gröning, K. (1997). Decorated skin. A world survey of body art. Thames \& Hudson.

Hegel, G. (1939). La Phénoménologie de l'Esprit. T. I. Aubier-Montaigne.

Jung, C. (1971). Les racines de la conscience. Buchet Chastel.

Lantéri-Laura, G. (1970). Histoire de la phrénologie. PUF.

Lorenz, K. (1985). La otra cara del espejo. Ensayo de una historia natural del conocimiento humano. Plaza y Janés.

Monod, J. (1971). El azar y la necesidad ensayo sobre la filosofía natural de la biología moderna. Barral Editores.

Nacar-Colunga (1962). Sagrada Biblia. Biblioteca de Autores Cristianos.

Pour la Science (2000). Léonard de Vinci. Les Génies de la Science, (3).

Rousseau, J. (1999). Discurso sobre el origen de la desigualdad entre los hombres. Biblioteca Virtual Miguel de Cervantes. https://bit.ly/3eLfnIO

Reina Valera (1960). Biblia. https://www.biblegateway.com/passage/?search=Juan\%2020\&version=RVR1960

Roy, C. (1957). Arts sauvages. Robert Delpire.

Schopenhauer, A. (1912). Le Monde comme volonté et comme représentation. Félix Alcan.

Sigerist, H. (1960). On the History of Medicine. Yale University School of Medicine.

Tinland, F. (1977). La différence anthropologique. Essai sur les raports de la nature et de l'artifice. Aubier-Montaigne.

Tisserand, P. (1924). Oeuvres de Maine de Biran Tome III: Mémoire sur la décomposition de la pensée. Félix Alcan.

White, R. (2000). Un big bang socioculturel: Une nouvelle façon d'apprehender le monde est née voici 40,000 ans. La Recherche, (4), 10-16. 